\title{
Minimally invasive oesophagectomy versus open esophagectomy for resectable esophageal cancer: a meta-analysis
}

\author{
Waresijiang Yibulayin, Sikandaer Abulizi, Hongbo Lv and Wei Sun ${ }^{*}$
}

\begin{abstract}
Background: Open esophagectomy (OE) is associated with significant morbidity and mortality. Minimally invasive oesophagectomy $(\mathrm{MIO})$ reduces complications in resectable esophageal cancer. The aim of this study is to explore the superiority of $\mathrm{MIO}$ in reducing complications and in-hospital mortality than OE.

Methods: MEDLINE, Embase, Science Citation Index, Wanfang, and Wiley Online Library were thoroughly searched. Odds ratio (OR)/weighted mean difference (WMD) with a 95\% confidence interval (Cl) was used to assess the strength of association.

Results: Fifty-seven studies containing 15,790 cases of resectable esophageal cancer were included. MIO had less intraoperative blood loss, short hospital stay, and high operative time $(P<0.05)$ than OE. MIO also had reduced incidence of total complications; $\left(\mathrm{OR}=0.700,95 \% \mathrm{Cl}=0.626 \sim 0.781, P_{V}<0.05\right)$, pulmonary complications $(\mathrm{OR}=0$. 527, $\left.95 \% \mathrm{Cl}=0431 \sim 0.645, P_{V}<0.05\right)$, cardiovascular complications $\left(\mathrm{OR}=0.770,95 \% \mathrm{Cl}=0.681 \sim 0.872, P_{V}<0.05\right)$, and surgical technology related (STR) complications $\left(\mathrm{OR}=0.639,95 \% \mathrm{Cl}=0.522 \sim 0.781, P_{V}<0.05\right)$, as well as lower in-hospital mortality $\left(\mathrm{OR}=0.668,95 \% \mathrm{Cl}=0.539 \sim 0.827, P_{V}<0.05\right)$. However, the number of harvested lymph nodes, intensive care unit (ICU) stay, gastrointestinal complications, anastomotic leak (AL), and recurrent laryngeal nerve palsy (RLNP) had no significant difference.
\end{abstract}

Conclusions: $\mathrm{MIO}$ is superior to $\mathrm{OE}$ in terms of perioperative complications and in-hospital mortality.

Keywords: Minimally invasive esophagectomy, Open esophagectomy, Complications, Mortality

\section{Background}

A global incidence of esophageal cancer has increased by $50 \%$ in the past two decades. Each year, around 482,300 people are diagnosed with esophageal cancer, and $84.3 \%$ die of the disease worldwide [1, 2]. At present, the primary method of treating patients with esophageal cancer has been surgery. However, the traditional open esophagectomy (OE) procedure has high complication rates resulting in significant morbidity and mortality $[3,4]$. Various studies showed inhospital mortality between 1.2 and $8.8 \%$ [4-7], even as high as $29 \%$ [8].

Minimally invasive oesophagectomy (MIO), which was first described in the 1990s $[9,10]$, was attributed to be

\footnotetext{
* Correspondence: yuan2559052@163.com

Department of Thoracic Surgery, Tumor Hospital of Xinjiang Medical University, Urumqi, China
}

(c) The Author(s). 2016 Open Access This article is distributed under the terms of the Creative Commons Attribution 4.0 International License (http://creativecommons.org/licenses/by/4.0/), which permits unrestricted use, distribution, and reproduction in any medium, provided you give appropriate credit to the original author(s) and the source, provide a link to the Creative Commons license, and indicate if changes were made. The Creative Commons Public Domain Dedication waiver (http://creativecommons.org/publicdomain/zero/1.0/) applies to the data made available in this article, unless otherwise stated.

superior in reducing postoperative outcomes, without compromising oncological outcomes and avoiding thoracotomy and laparotomy. The basis of minimally invasive techniques in esophageal surgery is to maintain the therapy effectiveness and quality of traditional operations, while reducing perioperative injury. Nevertheless, the real benefits of minimally invasive approach for esophagectomy are still controversial [11-13]. A number of meta-analyses and even randomized controlled trials demonstrated MIO to be superior in reducing risk of postoperative outcomes, but their results are not very consistent, especially on the issue of in-hospital mortality [14-30]. Furthermore, these studies ignored preoperative clinical data and other Chinese relevant literatures. We, therefore, performed a meta-analysis combining the relevant publications and comprehensively assess the superiority of MIO. 


\section{Materials and methods}

\section{Search strategy}

MEDLINE, Embase, Science Citation Index, Wanfang, and Wiley Online Library were thoroughly searched with terms "Minimally Invasive Esophagectomy" or "Open Esophagectomy," "Esophagectomy,"”MIE," "laparasc," "thoracosc," "VATS," "transhiatal" (date until May 2016). Relevant literatures containing full text were back tracked thoroughly, while abstracts and unpublished reports were excluded.

\section{Selections of studies}

Inclusion criteria The inclusion criteria are as follows: (1) randomized or non-randomized controlled studies with parallel controls, (2) comparison on OE versus MIO, (3) sufficient data of estimated odds ratios (ORs)/ weighted mean difference (WMD) and 95\% confidence intervals (CIs).

Exclusion criteria The exclusion criteria are as follows: (1) studies that were not compared or case report, (2) incomplete literature, and (3) overlapped studies.

\section{Data extraction}

Two investigators read all the included literatures carefully and extracted all the data, such as first author, published year, numbers of case and controls, outcomes of interest, etc. If two investigators have divergent ideas on any data, the third investigator would be asked to check and reach consensus on the data.

\section{Outcomes of interest}

(1) Definition of MIO was thoracoscopic/ laparotomy-assisted esophagectomy, hybrid minimally invasive esophagectomy, total thoracoscopic/hand-assisted thoracotomy, hand-assisted laparotomy, or minilaparotomy/ laparoscopic esophagectomy.

(2) Preoperative clinical data included age, neoadjuvant therapy, comorbidity, TNM staging, and gender.

(3) Postoperative data contained operative duration, blood loss, intensive care unit (ICU) stay, hospital stay, and harvested lymph nodes.

(4) The complications are as follows. (1) Mortality included in-hospital mortality and 30-day mortality. (2) Pulmonary complications included pneumonia, respiratory failure, adult respiratory distress syndrome (ARDS), etc. (3) Cardiovascular complications included arrhythmia, heart failure, acute myocardial infarction, deep vein thrombosis, pulmonary embolism, etc. (4) Gastrointestinal complications included gastric tip necrosis, anastomotic stricture, delayed gastric emptying, gastric volvulus, etc. (5) Surgical technology related (STR) complications included splenic laceration, tracheal laceration, pneumothorax, chylothorax, hemorrhage, etc.

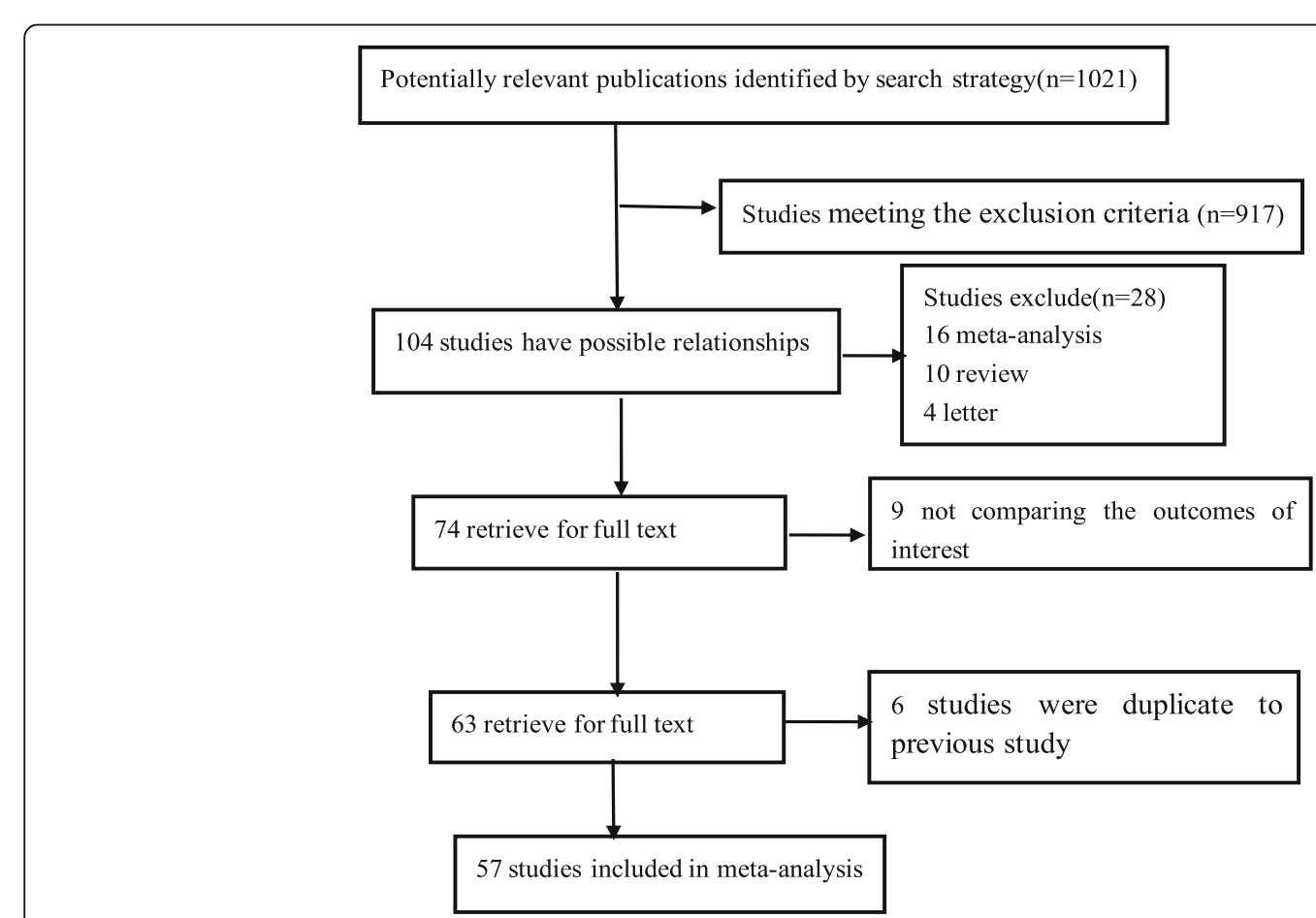

Fig. 1 Study flow chart explaining the selection of 57 studies included in the meta-analysis 
Table 1 Characteristics of included studies in this meta-analysis

\begin{tabular}{|c|c|c|c|c|c|c|c|c|c|c|c|c|c|}
\hline \multirow[t]{2}{*}{ Study } & \multirow[t]{2}{*}{ Year } & \multirow[t]{2}{*}{ Country } & \multirow{2}{*}{$\begin{array}{l}\text { Cases } \\
(\mathrm{MlO} / \mathrm{OE})\end{array}$} & \multirow{2}{*}{$\begin{array}{l}\text { Gender (M) } \\
\text { (MIO/OE) }\end{array}$} & \multirow{2}{*}{$\begin{array}{l}\text { Age, years } \\
\text { (MIO/OE) }\end{array}$} & \multirow{2}{*}{$\begin{array}{l}\text { NT } \\
(\mathrm{MIO} / \mathrm{OE})\end{array}$} & \multirow[t]{2}{*}{ NOS } & \multirow[t]{2}{*}{ Hybrid } & \multicolumn{3}{|c|}{ Preoperative comorbidity (MIO/OE) } & \multicolumn{2}{|c|}{ TNM stage (MIO/OE) } \\
\hline & & & & & & & & & Cardiovascular & Pulmonary & Diabetes & $0+1+11$ & III + IV \\
\hline Nguyen & 2000 & USA & $18 / 36$ & $7 / 29$ & $64 \pm 12 / 67 \pm 8$ & $9 / 9$ & 6 & MIE & NR & NR & NR & NR & NR \\
\hline Osugi & 2003 & Japan & $77 / 72$ & $64 / 57$ & $63.7 \pm 9 \cdot 6 / 64 \cdot \pm 9 \cdot 3$ & NR & 7 & TA & NR & NR & NR & NR & NR \\
\hline Kunisaki & 2004 & Japan & $15 / 30$ & $12 / 21$ & $62.3 \pm 8.1 / 63 \pm 6$ & NR & 6 & MIE & NR & NR & $N R$ & NR & $N R$ \\
\hline Bernabe & 2004 & USA & $17 / 14$ & $16 / 11$ & $63.9 \pm 13.5 / 64.1 \pm 10.7$ & NR & 6 & TA & NR & NR & NR & NR & NR \\
\hline Van den Broek & 2004 & Netherlands & $25 / 20$ & 19/14 & $63 \pm 8 / 64 \pm 8$ & $17 / 4$ & 7 & TA & NR & NR & NR & $8 / 10$ & $17 / 10$ \\
\hline Braghetto & 2006 & Chile & $47 / 119$ & NR & NR & $0 / 0$ & 8 & MIE & NR & NR & $N R$ & $41 / 80$ & $6 / 39$ \\
\hline Bresadola & 2006 & Italy & $14 / 14$ & $8 / 13$ & $61.9 \pm 7.7 / 59.3 \pm 10.9$ & NR & 6 & MIE & NR & NR & NR & $11 / 6$ & $3 / 8$ \\
\hline Shiraishi & 2006 & Japan & $116 / 37$ & $94 / 31$ & $61.5 \pm 8.1 / 66.5 \pm 9.3$ & $26 / 10$ & 7 & Hybrid & NR & NR & NR & NR & NR \\
\hline Smithers & 2007 & Australia & $332 / 114$ & $267 / 104$ & $64(27-85) / 62.5(29-81)$ & $136 / 29$ & 8 & Hybrid & $76 / 22$ & NR & $27 / 4$ & $192 / 36$ & $118 / 75$ \\
\hline Benzoni & 2007 & Italy & $9 / 13$ & $6 / 11$ & $63.6 \pm 2.6 / 60.2 \pm 2.4$ & $6 / 6$ & 8 & TA & NR & $2 / 4$ & $N R$ & $9 / 7$ & $0 / 6$ \\
\hline Fabian & 2008 & USA & $22 / 43$ & $16 / 31$ & $63(46-86) / 61(35-82)$ & $9 / 16$ & 7 & MIE & NR & NR & NR & $14 / 25$ & $7 / 19$ \\
\hline Parameswaran & 2009 & UK & $50 / 30$ & $45 / 21$ & $67(47-81) / 68(47-81)$ & $32 / 12$ & 8 & MIE & NR & NR & $N R$ & $27 / 17$ & 23/13 \\
\hline Saha & 2009 & UK & $16 / 28$ & $13 / 24$ & $65(50-80) / 64(35-78)$ & NR & 8 & MIE & NR & NR & NR & NR & NR \\
\hline Zingg & 2009 & Australia & $56 / 98$ & $45 / 71$ & $66.3 \pm 1.3 / 67.8 \pm 1.1$ & $40 / 48$ & 8 & MIE & $4 / 7$ & $13 / 35$ & $6 / 12$ & $35 / 47$ & $21 / 42$ \\
\hline Pham & 2010 & USA & $44 / 46$ & $41 / 33$ & $63 \pm 8.6 / 61 \pm 10.7$ & $29 / 23$ & 6 & MIE & NR & NR & NR & $20 / 20$ & 20/19 \\
\hline Perry & 2010 & USA & $21 / 21$ & $18 / 17$ & $69 \pm 8 / 61 \pm 9$ & NR & 7 & MIE & NR & NR & $N R$ & NR & $N R$ \\
\hline Hamouda & 2010 & UK & $51 / 24$ & $44 / 23$ & $62 / 60$ & $44 / 20$ & 7 & MIE & NR & NR & NR & NR & NR \\
\hline Safranek & 2010 & UK & $75 / 46$ & $53 / 38$ & $60(44-77) / 64(41-74)$ & $71 / 34$ & 7 & Hybrid & NR & NR & NR & $31 / 29$ & $44 / 17$ \\
\hline Schoppmann & 2010 & Australia & $31 / 31$ & $25 / 21$ & $61.5(36-75) / 58.6(34-77)$ & $15 / 7$ & 8 & MIE & $6 / 8$ & $10 / 8$ & $1 / 1$ & 18/19 & $13 / 12$ \\
\hline Schröder & 2010 & Germany & 238/181 & 198/151 & $61.1(60-62) / 57.8(56-59)$ & $144 / 66$ & 6 & TA & NR & NR & NR & NR & NR \\
\hline Mehran & 2011 & USA & $44 / 44$ & $43 / 40$ & $61.0(42-79) / 62.5(38-83)$ & $31 / 30$ & 7 & MIE & NR & NR & NR & $23 / 21$ & $16 / 20$ \\
\hline Berger & 2011 & USA & $65 / 53$ & $51 / 38$ & $61(41-78) / 62(40-86)$ & $28 / 43$ & 6 & MIE & NR & NR & $\mathrm{NR}$ & $52 / 41$ & 13/12 \\
\hline Lee & 2011 & Japan & $74 / 64$ & $73 / 61$ & $59.7 \pm 10.3 / 56.6 \pm 11.6$ & $47 / 52$ & 8 & Hybrid & NR & NR & NR & $54 / 49$ & $20 / 15$ \\
\hline Nafteux & 2011 & Belgium & $65 / 101$ & $52 / 81$ & $63(41-82) / 64(29-82)$ & NR & 8 & MIE & $11 / 24$ & $6 / 13$ & $6 / 12$ & NR & $N R$ \\
\hline Yamasaki & 2011 & Japan & 109/107 & $87 / 95$ & $64.6 \pm 8.5 / 64.7 \pm 8.0$ & $85 / 68$ & 8 & TA & $20 / 20$ & $11 / 13$ & $10 / 6$ & NR & $\mathrm{NR}$ \\
\hline Biere & 2012 & Netherlands & $59 / 56$ & $43 / 46$ & $62(34-75) / 62(42-75)$ & $59 / 56$ & 8 & MIE & NR & NR & $N R$ & $31 / 26$ & $15 / 19$ \\
\hline Maas & 2012 & Netherlands & $50 / 50$ & $41 / 33$ & $62.5(57-69) / 65(57-69)$ & $23 / 13$ & 8 & MIE & NR & NR & $N R$ & $19 / 19$ & $31 / 31$ \\
\hline Briez & 2012 & France & $140 / 140$ & $110 / 117$ & NR & $67 / 69$ & 8 & TA & NR & NR & $N R$ & $92 / 89$ & $48 / 51$ \\
\hline Kinjo & 2012 & Japan & $106 / 79$ & $87 / 70$ & $62.7 \pm 7.4 / 63.3 \pm 8.6$ & $54 / 11$ & 7 & MIE & NR & NR & NR & $65 / 45$ & $41 / 34$ \\
\hline Mamidanna & 2012 & UK & $1155 / 6347$ & $892 / 4870$ & NR & NR & 7 & MIE & $400 / 2234$ & $141 / 782$ & $90 / 598$ & NR & NR \\
\hline Sihag & 2012 & USA & $38 / 76$ & $29 / 61$ & $61.4 \pm 8.1 / 63.3 \pm 9.3$ & $25 / 46$ & 7 & MIE & $6 / 16$ & $8 / 13$ & NR & $29 / 53$ & $9 / 23$ \\
\hline Sundaram & 2012 & USA & $47 / 57$ & $38 / 52$ & $67.3(42-79) / 61.7(34-84)$ & $35 / 40$ & 8 & MIE & $33 / 42$ & NR & $11 / 14$ & NR & NR \\
\hline
\end{tabular}


Table 1 Characteristics of included studies in this meta-analysis (Continued)

\begin{tabular}{|c|c|c|c|c|c|c|c|c|c|c|c|c|c|}
\hline Tsujimoto & 2012 & Japan & $22 / 27$ & $21 / 21$ & $70 \pm 5.4 / 67 \pm 10.1$ & $8 / 16$ & 6 & $\mathrm{TA}$ & NR & $N R$ & $\mathrm{NR}$ & $12 / 14$ & $10 / 13$ \\
\hline Javidfar & 2012 & USA & $92 / 165$ & $71 / 122$ & $65(56-74) / 68(60-74)$ & $51 / 96$ & 7 & MIE & $9 / 23$ & $9 / 23$ & $22 / 35$ & $65 / 96$ & $27 / 69$ \\
\hline Bailey & 2013 & UK & $39 / 31$ & $32 / 27$ & $65(37-78) / 62(38-78)$ & $33 / 31$ & 7 & TA & NR & $N R$ & NR & $N R$ & NR \\
\hline Ichikawa & 2013 & Japan & $152 / 163$ & $129 / 145$ & $63.8 \pm 8.5 / 64.6 \pm 8.6$ & $54 / 64$ & 8 & TA & $23 / 35$ & $21 / 24$ & $26 / 37$ & $101 / 81$ & $51 / 79$ \\
\hline Kitagawa & 2013 & Japan & $45 / 47$ & $35 / 40$ & $63(47-77) / 64(39-83)$ & $8 / 11$ & 7 & MIE & NR & NR & $8 / 8$ & $N R$ & NR \\
\hline Noble & 2013 & UK & $53 / 53$ & $43 / 45$ & $66(45-85) / 64(36-81)$ & $13 / 11$ & 8 & MIE & NR & $N R$ & NR & $N R$ & NR \\
\hline Parameswaran & 2013 & UK & $67 / 19$ & $47 / 15$ & $64(45-84) / 64(51-77)$ & $50 / 17$ & 7 & Hybrid & NR & NR & NR & $43 / 8$ & $23 / 11$ \\
\hline Takeno & 2013 & Japan & $91 / 166$ & $77 / 147$ & $63.7 / 64.2$ & NR & 8 & TA & NR & $N R$ & NR & $N R$ & NR \\
\hline Kubo & 2014 & Japan & $135 / 74$ & $111 / 60$ & $64.1 \pm 8.2 / 62.2 \pm 7.2$ & $22 / 4$ & 7 & Hybrid & $12 / 3$ & $9 / 7$ & NR & $112 / 41$ & $23 / 33$ \\
\hline Schneider & 2014 & UK & $19 / 61$ & $46 / 15$ & $62.3(35-74) / 66.7(45-79)$ & $7 / 45$ & 6 & MIE & NR & NR & NR & $16 / 36$ & $2 / 24$ \\
\hline Daiko & 2015 & Japan & $31 / 33$ & $28 / 28$ & $66(49-78) / 65$ (49-76) & NR & 7 & MIE & NR & $N R$ & NR & $23 / 32$ & $8 / 1$ \\
\hline Kauppi & 2015 & Finland & $74 / 79$ & $59 / 68$ & $66(51-85) / 63(39-82)$ & $61 / 62$ & 8 & MIE & $14 / 17$ & $12 / 14$ & $17 / 13$ & $28 / 25$ & $46 / 54$ \\
\hline Law & 1997 & China & $18 / 63$ & $13 / 55$ & $66(43-80) / 63(36-84)$ & NR & 7 & MIE & NR & NR & NR & $5 / 15$ & $13 / 45$ \\
\hline Chen & 2010 & China & $67 / 38$ & $45 / 25$ & $61 \pm 7 / 66 \pm 6$ & NR & 7 & MIE & $15 / 4$ & $10 / 3$ & $9 / 2$ & $42 / 15$ & $25 / 23$ \\
\hline Gao & 2011 & China & $96 / 78$ & $89 / 70$ & $58.5 \pm 7.3 / 59.1 \pm 6.4$ & NR & 6 & MIE & NR & $N R$ & NR & $54 / 40$ & $42 / 38$ \\
\hline Shen & 2012 & China & $76 / 71$ & $52 / 50$ & $60.9 \pm 9 / 62.6 \pm 8.7$ & NR & 6 & MIE & $N R$ & NR & NR & $41 / 44$ & $35 / 27$ \\
\hline Liu & 2012 & China & $98 / 105$ & $67 / 71$ & $62.3 \pm 10.1 / 65.8 \pm 7.6$ & NR & 6 & MIE & $13 / 18$ & $40 / 37$ & $6 / 8$ & $51 / 43$ & $47 / 62$ \\
\hline Mao & 2012 & China & $34 / 38$ & $28 / 26$ & $62 / 60$ & NR & 6 & TA & NR & $N R$ & NR & $27 / 21$ & $7 / 17$ \\
\hline Wang & 2012 & China & $260 / 322$ & $194 / 232$ & $61.6 \pm 8.761 .2 \pm 8.8$ & $37 / 44$ & 6 & MIE & NR & NR & NR & $201 / 234$ & $59 / 88$ \\
\hline MU & 2014 & China & $176 / 142$ & $116 / 106$ & $60(55-66) / 59(54-62)$ & NR & 6 & MIE & NR & NR & NR & $120 / 109$ & $56 / 33$ \\
\hline Meng & 2014 & China & $94 / 89$ & $65 / 63$ & $59.7 \pm 9.3 / 61.1 \pm 6.7$ & NR & 7 & MIE & $11 / 14$ & $27 / 31$ & $12 / 10$ & $56 / 50$ & $38 / 39$ \\
\hline Zhang & 2014 & China & $60 / 61$ & $48 / 47$ & $62.4 \pm 8 / 61.8 \pm 8.4$ & NR & 6 & MIE & NR & NR & NR & $41 / 42$ & $19 / 19$ \\
\hline Chen & 2015 & China & $59 / 59$ & $42 / 40$ & $57(41-72) / 56(48-71)$ & NR & 7 & MIE & $4 / 2$ & $1 / 0$ & $2 / 3$ & $56 / 55$ & $3 / 4$ \\
\hline Yang & 2015 & China & $62 / 62$ & $45 / 45$ & $62 \pm 9 / 62 \pm 8$ & NR & 7 & MIE & NR & $N R$ & NR & $44 / 43$ & $18 / 19$ \\
\hline $\mathrm{Li}$ & 2015 & China & $89 / 318$ & $66 / 227$ & $73(70-83) / 73(70-85)$ & NR & 7 & MIE & NR & NR & NR & $64 / 188$ & $25 / 126$ \\
\hline
\end{tabular}


Table 2 Outcomes of complication in included studies

\begin{tabular}{|c|c|c|c|c|c|c|c|c|}
\hline Study & Total & Pulmonary & Circulatory system & Digestive system & $\mathrm{AL}$ & RLNP & STR & Mortality \\
\hline $\mathrm{MIO} / \mathrm{OE}$ & $\mathrm{MIO} / \mathrm{OE}$ & $\mathrm{MIO} / \mathrm{OE}$ & $\mathrm{MIO} / \mathrm{OE}$ & $\mathrm{MIO} / \mathrm{OE}$ & $\mathrm{MIO} / \mathrm{OE}$ & $\mathrm{MIO} / \mathrm{OE}$ & $\mathrm{MIO} / \mathrm{OE}$ & $\mathrm{MIO} / \mathrm{OE}$ \\
\hline Nguyen & NR & $2 / 6$ & $1 / 1$ & $1 / 2$ & $3 / 4$ & $0 / 4$ & $0 / 1$ & $0 / 1$ \\
\hline Osugi & $25 / 27$ & $12 / 14$ & $3 / 2$ & $N R$ & $2 / 1$ & $11 / 9$ & $4 / 4$ & NR \\
\hline Kunisaki & NR & $0 / 1$ & NR & $N R$ & $2 / 1$ & $3 / 3$ & NR & NR \\
\hline Bernabe & NR & $N R$ & NR & $7 / 8$ & NR & NR & NR & NR \\
\hline Van den Broek & $14 / 18$ & $2 / 2$ & NR & $3 / 5$ & $2 / 3$ & $2 / 3$ & $2 / 4$ & NR \\
\hline Braghetto & $18 / 72$ & $7 / 22$ & $0 / 3$ & $4 / 6$ & $3 / 17$ & $0 / 2$ & $1 / 0$ & $3 / 13$ \\
\hline Bresadola & NR & $1 / 2$ & $1 / 0$ & NR & $1 / 2$ & $3 / 1$ & NR & NR \\
\hline Shiraishi & NR & $25 / 12$ & $13 / 9$ & NR & $12 / 9$ & $42 / 10$ & NR & $6 / 5$ \\
\hline Smithers & $207 / 76$ & $106 / 44$ & $60 / 24$ & $83 / 9$ & $17 / 11$ & $8 / 0$ & $25 / 14$ & $7 / 3$ \\
\hline Benzoni & NR & $0 / 2$ & NR & $0 / 1$ & $1 / 1$ & $1 / 1$ & NR & $0 / 1$ \\
\hline Fabian & $15 / 31$ & $1 / 18$ & $5 / 8$ & $1 / 0$ & $3 / 3$ & $1 / 2$ & $0 / 3$ & $1 / 4$ \\
\hline Parameswaran & $24 / 15$ & $4 / 2$ & $0 / 3$ & $3 / 1$ & $4 / 1$ & $6 / 0$ & $5 / 4$ & NR \\
\hline Saha & $3 / 6$ & $N R$ & NR & $N R$ & $2 / 3$ & $N R$ & NR & $0 / 2$ \\
\hline Zingg & $19 / 20$ & $17 / 33$ & NR & $N R$ & $11 / 11$ & NR & $2 / 2$ & $2 / 6$ \\
\hline Pham & $34 / 27$ & $13 / 9$ & $18 / 16$ & $3 / 1$ & $4 / 5$ & $6 / 0$ & $3 / 10$ & $3 / 2$ \\
\hline Perry & $13 / 17$ & $2 / 3$ & $5 / 8$ & $5 / 4$ & $4 / 6$ & $1 / 2$ & $2 / 5$ & NR \\
\hline Hamouda & NR & $15 / 5$ & $5 / 3$ & $3 / 1$ & $4 / 2$ & NR & $3 / 0$ & NR \\
\hline Safranek & NR & 19/13 & NR & $17 / 4$ & $11 / 1$ & $10 / 1$ & $5 / 5$ & $3 / 1$ \\
\hline Schoppmann & NR & $5 / 17$ & NR & $0 / 1$ & $1 / 8$ & $4 / 13$ & $3 / 4$ & NR \\
\hline Schröder & NR & $N R$ & NR & NR & 18/17 & NR & NR & $7 / 11$ \\
\hline Mehran & NR & $14 / 15$ & $9 / 9$ & $18 / 8$ & $11 / 6$ & NR & NR & NR \\
\hline Berger & $31 / 32$ & $10 / 22$ & $1 / 6$ & $N R$ & $9 / 6$ & NR & NR & $5 / 4$ \\
\hline Lee & NR & $11 / 20$ & $N R$ & $N R$ & $10 / 18$ & NR & NR & $4 / 8$ \\
\hline Nafteux & $44 / 61$ & $17 / 47$ & $11 / 13$ & $13 / 6$ & $5 / 10$ & $N R$ & $6 / 9$ & $2 / 2$ \\
\hline Yamasaki & $26 / 38$ & $7 / 15$ & $3 / 6$ & $0 / 2$ & $6 / 4$ & $17 / 20$ & $3 / 5$ & $0 / 2$ \\
\hline Biere & NR & $14 / 35$ & $1 / 1$ & $1 / 0$ & $7 / 4$ & $1 / 8$ & $1 / 1$ & $3 / 1$ \\
\hline Maas & $21 / 33$ & $9 / 13$ & $3 / 6$ & NR & $4 / 3$ & $3 / 5$ & $2 / 5$ & $0 / 1$ \\
\hline Briez & $50 / 83$ & $22 / 60$ & NR & $6 / 4$ & $8 / 6$ & NR & NR & $2 / 10$ \\
\hline Kinjo & $54 / 54$ & $22 / 31$ & $10 / 5$ & $8 / 9$ & $11 / 13$ & $21 / 10$ & $4 / 10$ & NR \\
\hline Mamidanna & NR & $276 / 1419$ & $165 / 1035$ & $N R$ & NR & NR & NR & $46 / 274$ \\
\hline Sihag & NR & $1 / 33$ & $5 / 19$ & $N R$ & $0 / 2$ & NR & $3 / 5$ & $0 / 2$ \\
\hline Sundaram & $28 / 41$ & $5 / 19$ & $9 / 19$ & $26 / 10$ & $4 / 4$ & $1 / 1$ & 10/11 & $2 / 1$ \\
\hline Tsujimoto & $13 / 16$ & $2 / 10$ & $N R$ & $1 / 1$ & $7 / 3$ & $2 / 2$ & $1 / 4$ & $1 / 5$ \\
\hline Javidfar & NR & $9 / 26$ & $29 / 56$ & $19 / 33$ & $5 / 7$ & $3 / 0$ & $22 / 38$ & $3 / 7$ \\
\hline Bailey & NR & $15 / 18$ & $4 / 9$ & $1 / 0$ & $1 / 0$ & NR & $6 / 15$ & $2 / 2$ \\
\hline Ichikawa & $94 / 117$ & $20 / 33$ & $17 / 38$ & $4 / 5$ & $14 / 27$ & $60 / 77$ & $2 / 2$ & $0 / 8$ \\
\hline Kitagawa & NR & $6 / 14$ & $N R$ & $N R$ & NR & $N R$ & $13 / 20$ & $2 / 1$ \\
\hline Noble & NR & $14 / 18$ & $10 / 7$ & $N R$ & $5 / 2$ & NR & $2 / 2$ & $1 / 1$ \\
\hline Parameswaran & $42 / 12$ & $7 / 2$ & $2 / 1$ & $14 / 2$ & NR & $2 / 1$ & $6 / 3$ & $3 / 1$ \\
\hline Takeno & $39 / 69$ & $N R$ & $N R$ & $N R$ & NR & NR & NR & $4 / 15$ \\
\hline Kubo & $57 / 35$ & $13 / 16$ & NR & $2 / 0$ & $10 / 7$ & $37 / 14$ & 18/19 & $2 / 2$ \\
\hline Schneider & $7 / 13$ & NR & $N R$ & $N R$ & NR & NR & NR & $0 / 2$ \\
\hline Daiko & $10 / 12$ & NR & NR & NR & $6 / 4$ & $3 / 6$ & $2 / 6$ & NR \\
\hline
\end{tabular}


Table 2 Outcomes of complication in included studies (Continued)

\begin{tabular}{|c|c|c|c|c|c|c|c|c|}
\hline Kauppi & $37 / 48$ & $13 / 15$ & $17 / 27$ & $5 / 14$ & $5 / 5$ & $0 / 4$ & $12 / 11$ & NR \\
\hline Law & NR & $4 / 15$ & $3 / 16$ & NR & $0 / 2$ & $4 / 8$ & NR & NR \\
\hline Chen & NR & $7 / 10$ & NR & $2 / 0$ & $1 / 0$ & NR & $2 / 1$ & NR \\
\hline Gao & $31 / 36$ & $13 / 11$ & NR & $7 / 12$ & $7 / 6$ & $2 / 4$ & $1 / 2$ & $2 / 3$ \\
\hline Shen & $32 / 28$ & $5 / 6$ & $9 / 8$ & $1 / 1$ & $16 / 14$ & $7 / 2$ & $2 / 3$ & $0 / 1$ \\
\hline Liu & $22 / 38$ & $5 / 21$ & $4 / 13$ & $3 / 5$ & $2 / 4$ & $3 / 4$ & $3 / 5$ & $1 / 3$ \\
\hline Mao & $14 / 16$ & $0 / 2$ & $1 / 6$ & $0 / 1$ & $8 / 1$ & $5 / 3$ & NR & $N R$ \\
\hline Wang & $90 / 145$ & $12 / 23$ & $21 / 36$ & $11 / 13$ & $26 / 32$ & $6 / 7$ & $8 / 16$ & $2 / 11$ \\
\hline$M U$ & $28 / 22$ & $6 / 4$ & NR & $N R$ & $12 / 4$ & NR & NR & $1 / 1$ \\
\hline Meng & $24 / 41$ & $9 / 24$ & $4 / 11$ & $2 / 2$ & $6 / 7$ & $4 / 4$ & $3 / 4$ & $1 / 4$ \\
\hline Zhang & NR & $4 / 7$ & $3 / 5$ & $3 / 2$ & $3 / 2$ & $2 / 1$ & $2 / 7$ & $N R$ \\
\hline Chen & $14 / 19$ & $2 / 4$ & $3 / 5$ & NR & $2 / 3$ & $4 / 5$ & $1 / 1$ & NR \\
\hline Yang & 19/31 & NR & NR & NR & NR & $N R$ & NR & $N R$ \\
\hline $\mathrm{Li}$ & $32 / 137$ & $8 / 51$ & $9 / 34$ & $2 / 5$ & $19 / 45$ & $18 / 49$ & $4 / 19$ & $3 / 16$ \\
\hline
\end{tabular}

$A L$ anastomotic leak, RLNP recurrent laryngeal nerve palsy, STR surgical technology-related, Mortality in-hospital/30-day mortality

\section{Statistical analysis}

Data was analyzed using STATA 11 (Stata Corp LP, College Station, Texas, 2011). Fixed or random effects models [31] were used. Odds ratio (OR) was used for categorical variables, while weighted mean difference (WMD) was used for continuous variables, such as operative time, harvested lymph nodes, and blood loss [32]. Q test was used to check the heterogeneity among each study. If the heterogeneity was high $\left(I^{2}>50 \%\right)$, Random Effects Model was used to calculate the pooled OR/WMD. Otherwise, the fixed effects model was used [33]. If the heterogeneity test was statistically significant, sensitivity analysis, subgroup analysis,

Table 3 Differences between MIO and OE surgery patients

\begin{tabular}{|c|c|c|c|c|c|c|}
\hline$\underline{\text { Variables }}$ & No. studies & WMD/OR $(95 \% \mathrm{Cl})$ & $P_{V}$ & $P_{Q}$ & $P^{2}(\%)$ & $P_{E}$ \\
\hline Age, years & $57(n=15790)$ & $-0.343(-1.200,0.514)$ & 0.433 & $<0.05$ & 68.1 & 0.059 \\
\hline NT & $34(n=5138)$ & $1.364(1.042,1.785)$ & 0.024 & $<0.05$ & 73.0 & 0.362 \\
\hline \multicolumn{7}{|l|}{ Comorbidity } \\
\hline Cardiovascular & $16(n=10337)$ & $0.913(0.815,1.022)$ & 0.112 & 0.030 & 44.2 & 0.930 \\
\hline Pulmonary & $15(n=9779)$ & $0.949(0.819,1.099)$ & 0.485 & 0.881 & 0 & 0.722 \\
\hline Diabetes & $15(n=9983)$ & $0.942(0.798,1.111)$ & 0.476 & 0.457 & 0 & 0.082 \\
\hline Operating time, $\min$ & $46(n=6260)$ & $24.427(10.912,37.943)$ & $<0.05$ & $<0.05$ & 96.1 & 0.155 \\
\hline Blood loss, ml & $40(n=5285)$ & $-196.060(-255.195,-136.926)$ & $<0.05$ & $<0.05$ & 98.9 & 0.592 \\
\hline LN harvest & $46(n=6390)$ & $-1.275(-5.851,3.301)$ & 0.585 & $<0.05$ & 99.8 & 0.786 \\
\hline LOS, day & $45(n=13899)$ & $-3.660(-4.891,-2.428)$ & $<0.05$ & $<0.05$ & 86.0 & 0.175 \\
\hline ICU stay, day & $27(n=10761)$ & $-1.599(-2.680,-0.518)$ & 0.004 & $<0.05$ & 98.2 & 0.078 \\
\hline \multicolumn{7}{|l|}{ Complication } \\
\hline Total complication & $35(n=5991)$ & $0.700(0.626,0.781)$ & $<0.05$ & 0.012 & 38.5 & 0.178 \\
\hline Pulmonary & $50(n=14781)$ & $0.527(0.431,0.645)$ & $<0.05$ & $<0.05$ & 60.3 & $<0.05$ \\
\hline Circulatory system & $36(n=12883)$ & $0.770(0.681,0.872)$ & $<0.05$ & 0.427 & 2.4 & 0.386 \\
\hline Digestive system & $21(n=4081)$ & $1.097(0.835,1.442)$ & 0.507 & 0.083 & 31.7 & 0.664 \\
\hline$A L$ & $50(n=7528)$ & $1.023(0.870,1.202)$ & 0.785 & 0.304 & 8.5 & 0.018 \\
\hline RLNP & $37(n=5429)$ & $1.108(0.917,1.339)$ & 0.289 & 0.089 & 24.8 & 0.014 \\
\hline STR & $39(n=5991)$ & $0.639(0.522,0.781)$ & $<0.05$ & 0.918 & 0 & 0.206 \\
\hline Mortality & $38(n=14132)$ & $0.668(0.539,0.827)$ & $<0.05$ & 0.944 & 0 & 0.508 \\
\hline
\end{tabular}

$N T$ neoadjuvant therapy, $L N$ lymph node, $L O S$ length of hospital stay, ICU intensive care unit, $A L$ anastomotic leak, RLNP recurrent laryngeal nerve palsy, STR surgical technology-related, Mortality in-hospital/30-day mortality, $P_{V}$ the $P$ value for pooled, $P_{Q}$ the $P$ value for $Q$ test, $P_{E}$ the $P$ value for Egger's test 
and Galbraith Plot Analysis were performed to find out potential origin of heterogeneity. Egger's Test and Begg's Funnel Plot were used for diagnosis of potential publication bias [34]. A $P$ value $<0.05$ was considered as statistical significance. Duval and Tweedie nonparametric "trim and fill" procedure was used to assess the possible effect of publication bias [35].

The Newcastle Ottawa Quality Assessment Scale was used to assess the validity and quality of studies [36], as recommended in the Cochrane Handbook [37]. This scale assigns a star rating based on pre-specified criteria. A total number of quality star ranged from one (low quality) to nine (high quality). A maximum of one star can be attained for each category, except comparability, which has maximum of two stars. The more the stars, the higher is the quality of study.

\section{Results}

\section{Study characteristics}

A flow chart of the literature search process is shown in Fig. 1. A total of 1021 unique records were identified by search strategy; 917 records were excluded; 16 studies were meta-analyses or systematic overviews [14-19]; ten were review; and four were letter; nine studies did not compare the outcomes of interest [3, 5-12], and six studies were duplicate to previous study. Therefore, 57 studies containing 15,790 cases (both MIO and OE) were included in this meta-analysis [30, 38-93].

Preoperative clinical data as well as quality star ranging from 6 to 8 are shown in Table 1. Of 15,790 cases, 5235 (33.2\%) were MIO and 10,555 (66.8\%) were OE. Thirty one studies were done in European countries and 26 in Asian countries, where 13 were from China [45-57]. Moreover, 39 studies involved total MIE, 12 studies thoracoscopic-assisted MIE (TA), and seven studies were hybrid (TA + MIE). TNM staging were reported in 40 studies (6265 cases), where 1973 patients (64.4\%) in the MIO group and 1042 patients $(32.5 \%)$ in the OE group were of early stage (stages I and II), mainly male $(78.4 \%$ (MIO) vs 68.3\% (OE)).

\section{Preoperative clinical data}

Fifty-seven studies reported patient's age. There was no statistical significance between two groups after pooled

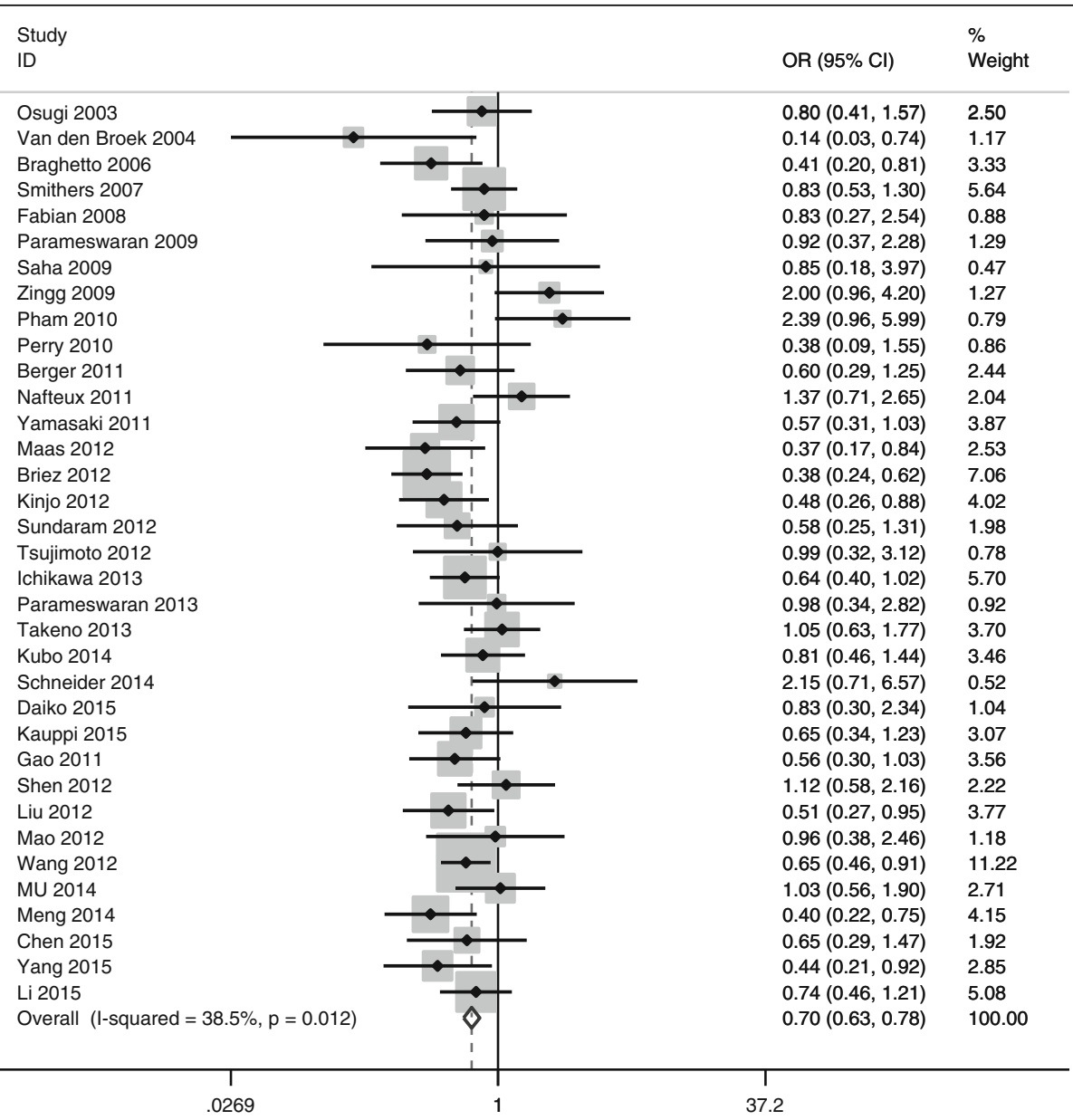

Fig. 2 Meta-analysis for MIE and total complications 
analysis $\left(\mathrm{WMD}=-0.343,95 \% \mathrm{CI}=-1.200 \sim 0.514, P_{V}<\right.$ $0.433)$. Thirty-three studies (5243 cases) reported that the patients in MIE group received more neoadjuvant therapy (Table 3, pooled OR $=1.364,95 \% \mathrm{CI}=1.042 \sim$ $\left.1.785, P_{V}=0.024\right)$. Sixteen studies reported preoperative comorbidity, where there was no statistical significance between two groups $\left(P_{V}>0.05\right)$.

\section{Postoperative data}

Forty-six studies (6260 cases) reported that operative time was higher in MIO group (Table 3, pooled WMD = $\left.1.364,95 \% \mathrm{CI}=10.912 \sim 37.943, P_{V}<0.05\right)$. Forty studies (5285 cases) reported less blood loss in MIO group $\left(\mathrm{WMD}=-196, \quad 95 \% \quad \mathrm{CI}=-255.195 \sim-136.926, \quad P_{V}<\right.$ $0.05)$. Duration of hospital stay (13,899 cases), including ICU stay (10,761 cases), were found to be significantly lower in MIO group $(\mathrm{WMD}=-1.599,95 \% \mathrm{CI}=(-2.680$ $\sim-0.518, P_{V}<0.05$ and $\mathrm{WMD}=-3.66,95 \% \mathrm{CI}=-4.891$ $\left.\sim-2.428, P_{V}<0.05\right)$. There was no significant difference between two groups in forty-six studies (6390 cases) reported for harvested lymph nodes (Table $3, \mathrm{WMD}=$ $\left.-1.275,95 \% \mathrm{CI}=-5.851 \sim 3.301, P_{V}=0.585\right)$. There was significant heterogeneity in the outcome among all the indices of postoperative data. Stratified analysis was performed according to ethnicity (Asian/Caucasian); however, heterogeneity still existed in subgroups. We then gradually removed small sample size, with emphasis on not altering the overall qualitative results.

\section{Complications \\ MIO and total complications}

Thirty-five studies including 5991 cases reported total complications, where $41.5 \%(1206 / 2907)$ were allocated to MIE group and $48.2 \%$ (1486/3084) were allocated to OE group, with overall morbidity of $44.9 \%(2692 / 5991)$ (see Table 2).

Low heterogeneity was found among studies $\left(I^{2}=\right.$ $\left.38.5 \%, P_{Q}=0.012\right)$, so the fixed effects model was used (see Table 3). The pooled $\mathrm{OR}=0.70,95 \% \mathrm{CI}=0.626 \sim$ $0.781, P_{V}<0.05$ indicated total complication was significantly lower in MIO group (Fig. 2). Publication bias was assessed by Egger's Test and Begg's Funnel Plot; no publication bias could be discovered $\left(P_{E}=0.178\right)$.

\section{MIO and pulmonary complications}

Fifty studies including 14,781 cases reported pulmonary complications, where $17.1 \%(813 / 4761)$ were in MIO group and $22.6 \%(2264 / 10,020)$ were in OE group, with overall morbidity of $20.8 \%(3077 / 14,781)$.

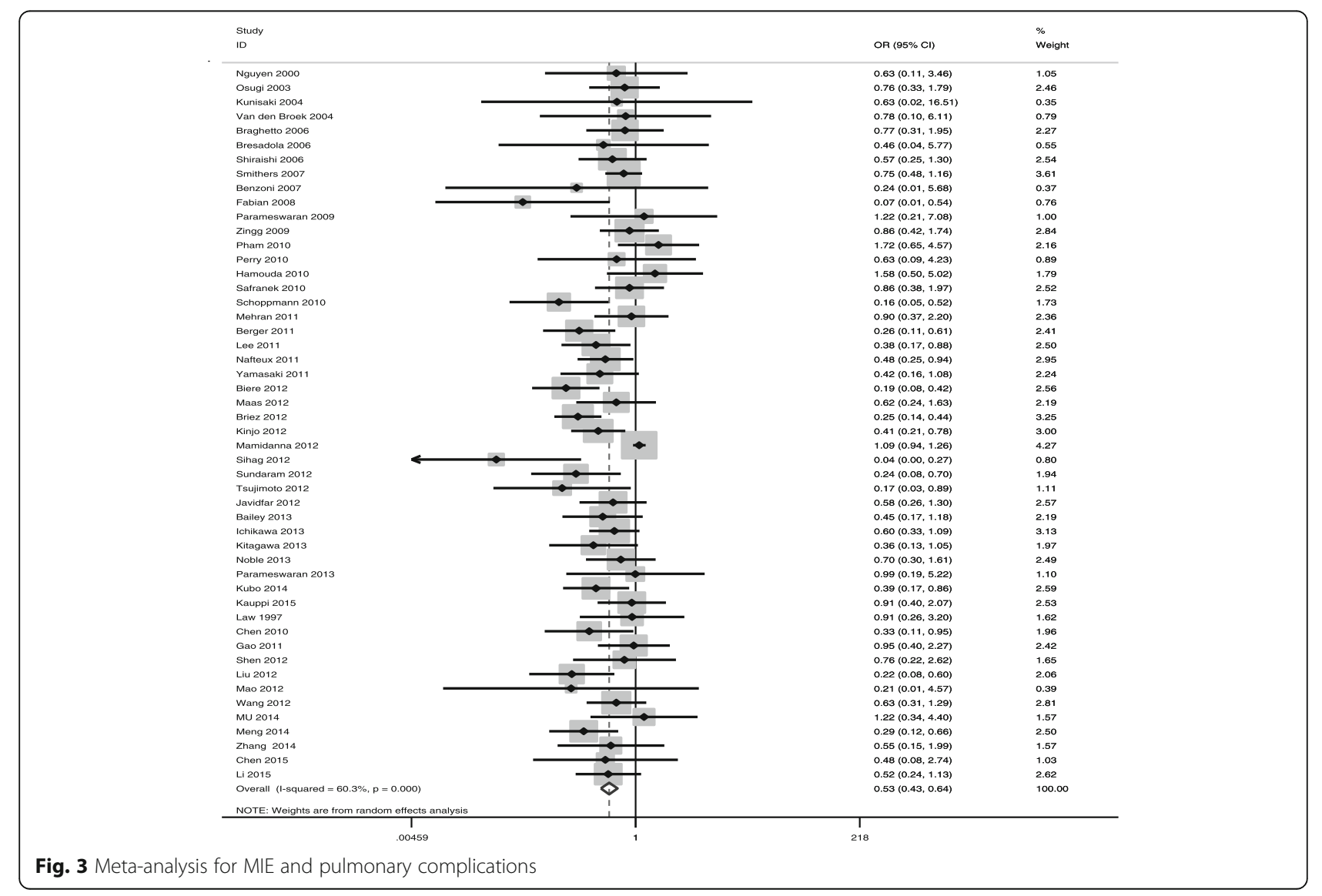




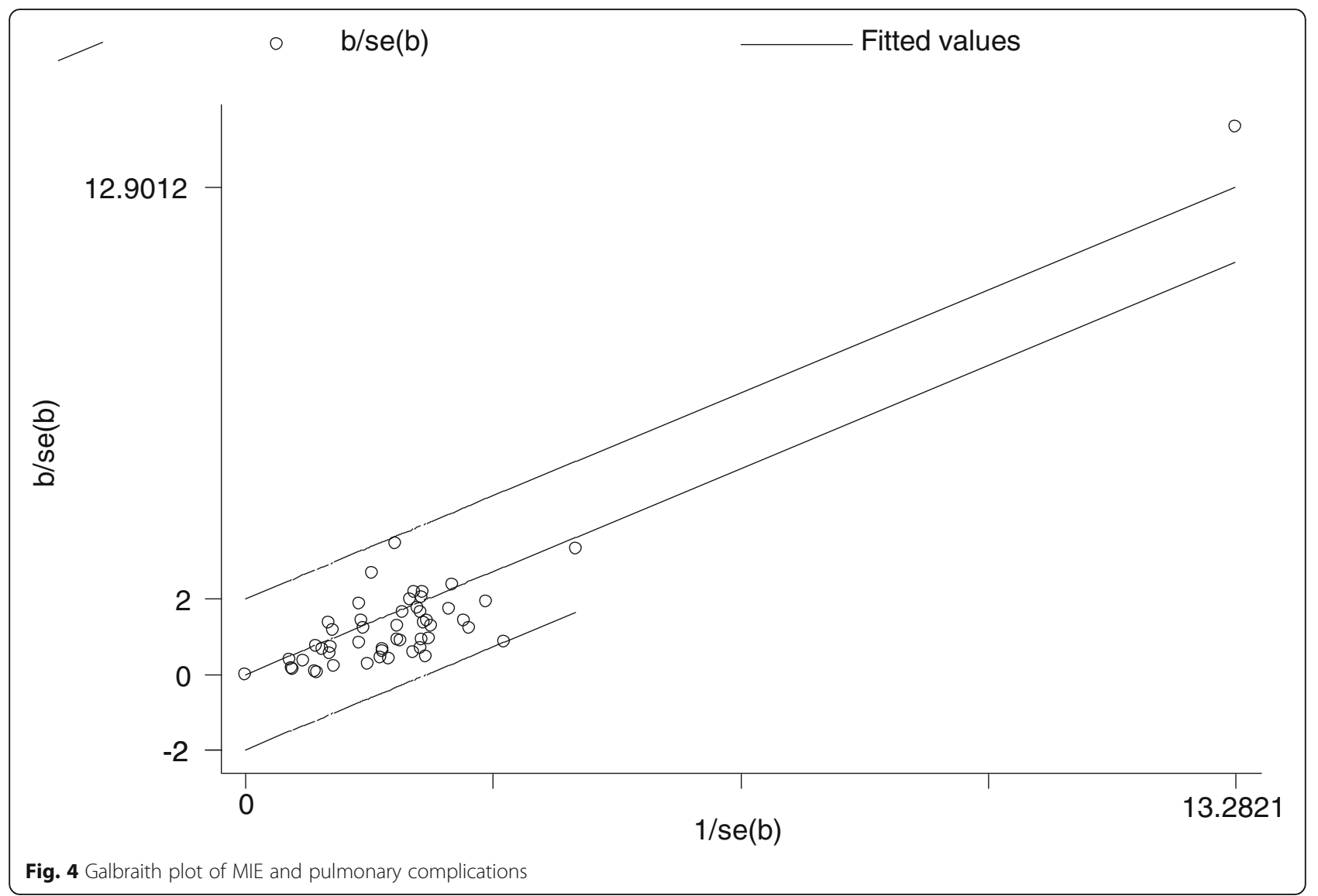

There was very strong evidence of reduced risk of pulmonary complications in the MIO group $(\mathrm{OR}=$ $\left.0.527,95 \% \mathrm{CI}=0.431 \sim 0.645, P_{V}<0.05\right)$, with statistical heterogeneity $\left(I^{2}\right.$ of $\left.60.3 \%, P_{Q}=0.012\right)$ (Fig. 3, Table 3 ). In order to find out other sources of heterogeneity,
Galbraith Plot Analysis was performed to identify which study results in the heterogeneity (Fig. 4). Pham et al. [52] and Mamidanna et al. [66] were outliers from the Galbraith Plot Analysis and $I^{2}$ values decreased after removing the study (OR $=0.502$ 95\%

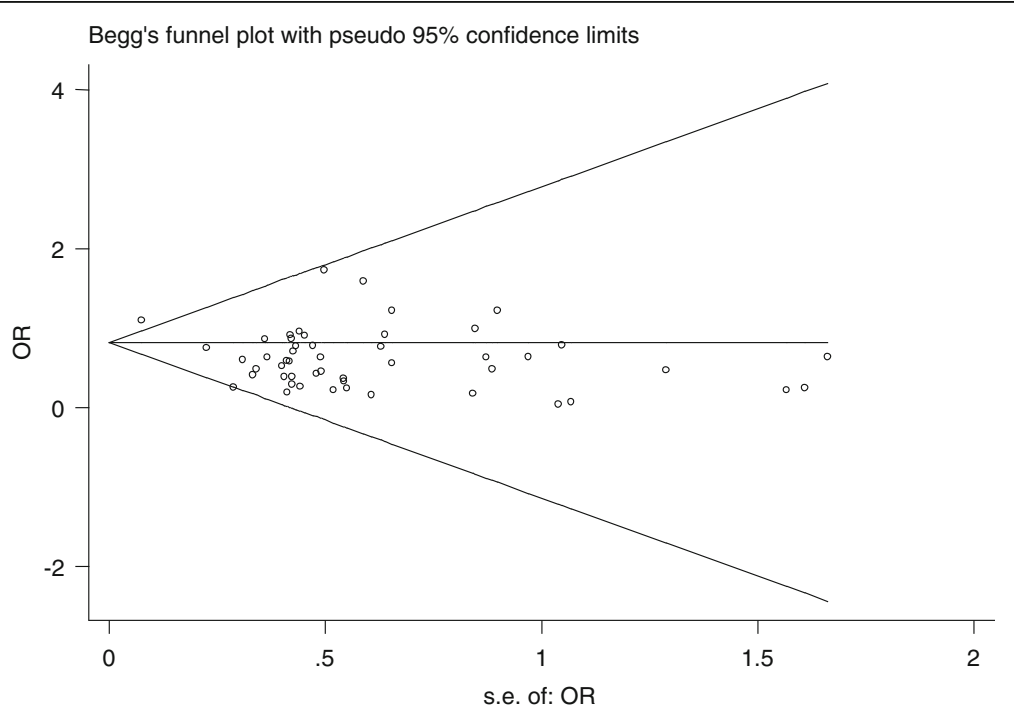

Fig. 5 Begg's Test of MIE and pulmonary complications 
$\left.\mathrm{CI}=0.425 \sim 0.592, \quad P_{V}<0.05, \quad I^{2}=26.6 \%, \quad P_{Q}=0.05\right)$. However, the funnel plot figure (Fig. 5) showed significant statistical difference $\left(P_{E}<0.05\right)$, indicating the possibility of publication bias.

\section{MIO and mortality}

Thirty-eight studies addressed the mortality (MIO 4379 vs $\mathrm{OE}$ 9753). The mortality risk was $3.8 \%$ (124/4379) in MIO group versus $4.5 \%$ (437/9753) in OE group. There was very strong evidence of reduced mortality in MIO group $\left(\mathrm{OR}=0.668,95 \% \mathrm{CI}=0.539 \sim 0.827, P_{V}<0.05\right)$, with statistical homogeneity $\left(I^{2}\right.$ of $\left.0 \%, P_{Q}=0.944\right)$ (Fig. 6).

\section{MIO and cardiovascular complications}

Thirty-six studies reported cardiovascular complications (MIO 3745 vs OE 9138). There was very strong evidence of reduced cardiovascular complications in MIO group $\left(\mathrm{OR}=0.770, \quad 95 \% \mathrm{CI}=0.681 \sim 0.872, \quad P_{V}<0.05\right)$, with statistical homogeneity ( $I^{2}$ of $\left.2.4 \%, P_{Q}=0.427\right)$ (Fig. 7).
MIO and surgical technology related (STR) complications

Thirty-nine studies reported STR complications (MIO2933 vs OE 3058). There was very strong evidence of reduced STR complications in MIO group (OR = $\left.0.770,95 \% \mathrm{CI}=0.681 \sim 0.872, P_{V}<0.05\right)$, with statistical homogeneity $\left(I^{2}\right.$ of $\left.2.4 \%, P_{Q}=0.918\right)$ (Fig. 8 and Table 3 ).

\section{MIO and gastrointestinal complications}

Twenty-one studies reported gastrointestinal complications (MIO 1872 vs OE 2209). There was no evidence of reduced gastrointestinal complications in $\mathrm{MIO}$ group $\left(\mathrm{OR}=1.097,95 \% \mathrm{CI}=0.835 \sim 1.442, P_{V}=0.507\right)$, with statistical homogeneity $\left(I^{2}\right.$ of $\left.31.7 \%, \quad P_{Q}=0.083\right)$ (Table 3).

\section{MIO and anastomotic leak (AL)}

Fifty studies reported anastomotic leak (MIO 3680 vs $\mathrm{OE}$ 3848). There was no evidence of reduced anastomotic leak in $\mathrm{MIO}$ group $(\mathrm{OR}=1.023,95 \% \mathrm{CI}=0.870$ $\left.1.202, P_{V}=0.785\right)$, with statistical homogeneity ( $I^{2}$ of $8.5 \%, P_{\mathrm{Q}}=0.304$ ) (Table 3 ).

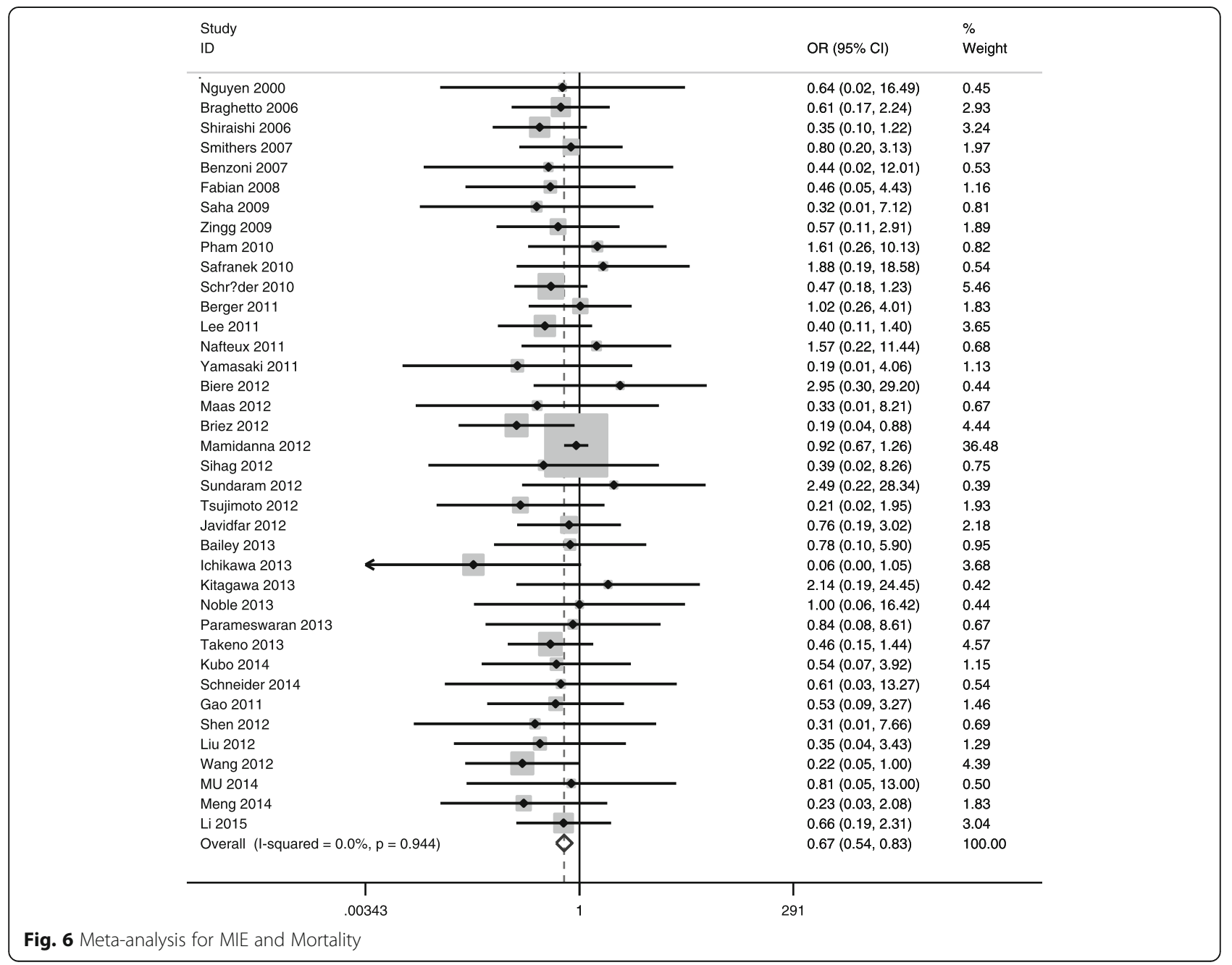




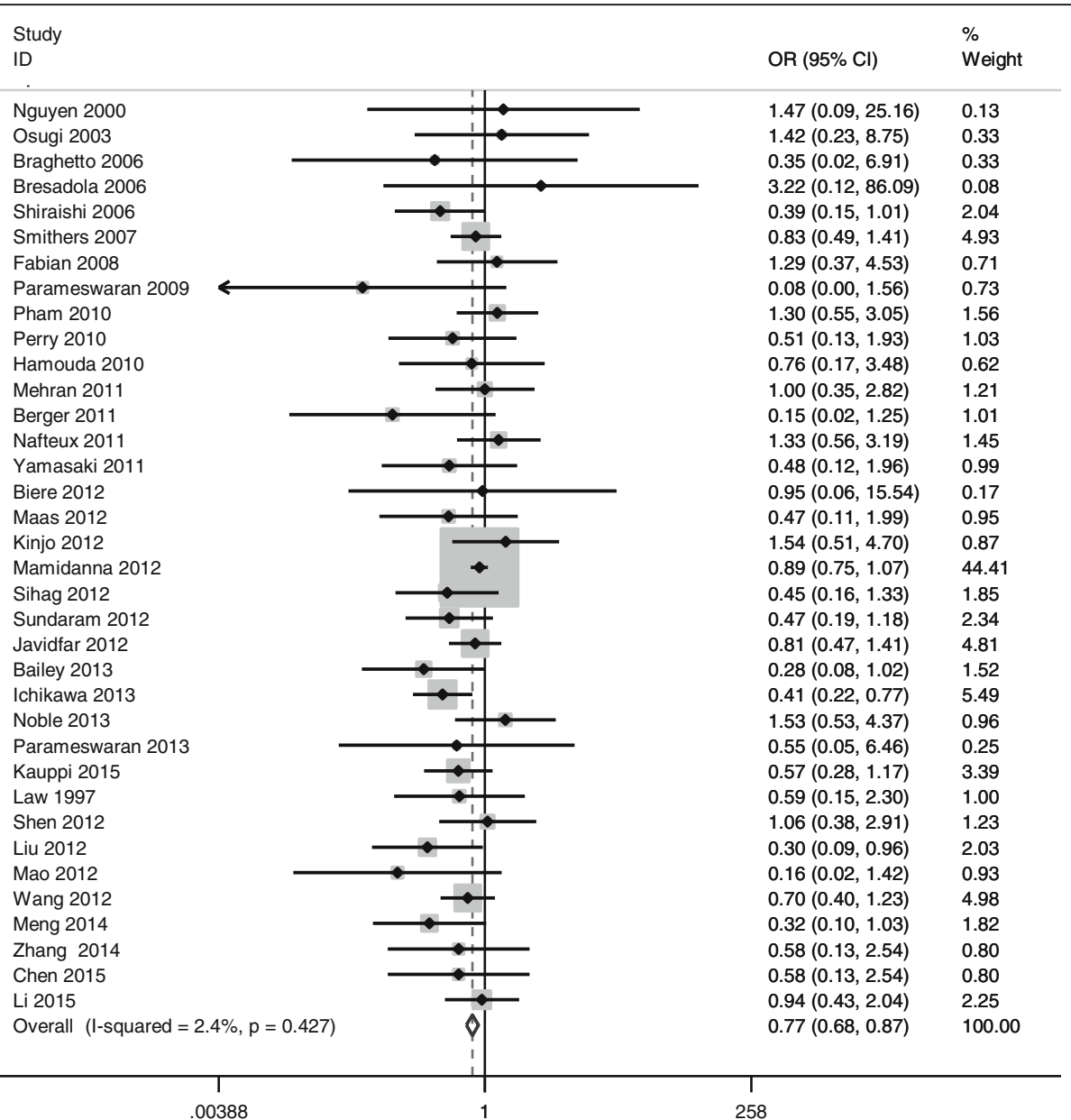

Fig. 7 Meta-analysis of MIE and cardiovascular complications

MIO and recurrent laryngeal nerve palsy (RLNP)

Thirty-seven studies reported recurrent laryngeal nerve palsy (MIO 2624 vs OE 2805). There was no evidence of reduced RLNP in MIO group $(\mathrm{OR}=1.108,95 \% \mathrm{CI}=$ $0.917 \sim 1.339, P_{V}=0.289$ ), with statistical homogeneity $\left(I^{2}\right.$ of $\left.24.8 \%, P_{\mathrm{Q}}=0.089\right)$ (Table 3$)$.

\section{Publication bias analysis}

Publication bias was assessed by Egger's Test and Begg's Funnel Plot. Begg's Funnel Plot is shown in Fig. 5, with significant statistical difference $\left(P_{E}<0.05\right)$ (Table 3). This indicated the possibility of publication bias, so sensitivity analysis using "trim and fill" method was carried out, with the aim to impute hypothetically negative unpublished studies, to mirror the positive studies that cause funnel plot asymmetry [35], and to show consistent and stable results between MIO and pulmonary complications (Fig. 9), anastomotic leak, and recurrent laryngeal nerve palsy.

\section{Sensitivity analysis}

As sample size for cases and controls in all studies is not same (ranging from 9 to 6347), we gradually removed small sample size without altering the qualitative overall results. According to the sensitivity analysis shown in Fig. 10, we removed the Mamidanna et al. [66], without alteration, where $I^{2}$ values decreased, indicating that the results were stable.

\section{Discussion}

MIO has been investigated for decades and is considered to be advantageous compared to OE. However, in the previous studies, the analyzed groups of patients who underwent MIO were small and the reports were mostly retrospective comparative studies, and there was no consensus as to which operative method is superior [94]. Therefore, an updated meta-analysis is performed, which includes the largest and the most complete collections of published data.

We found higher operative duration in the MIO group, consistent with Kunisaki's [40], Shiraishi's [45], 


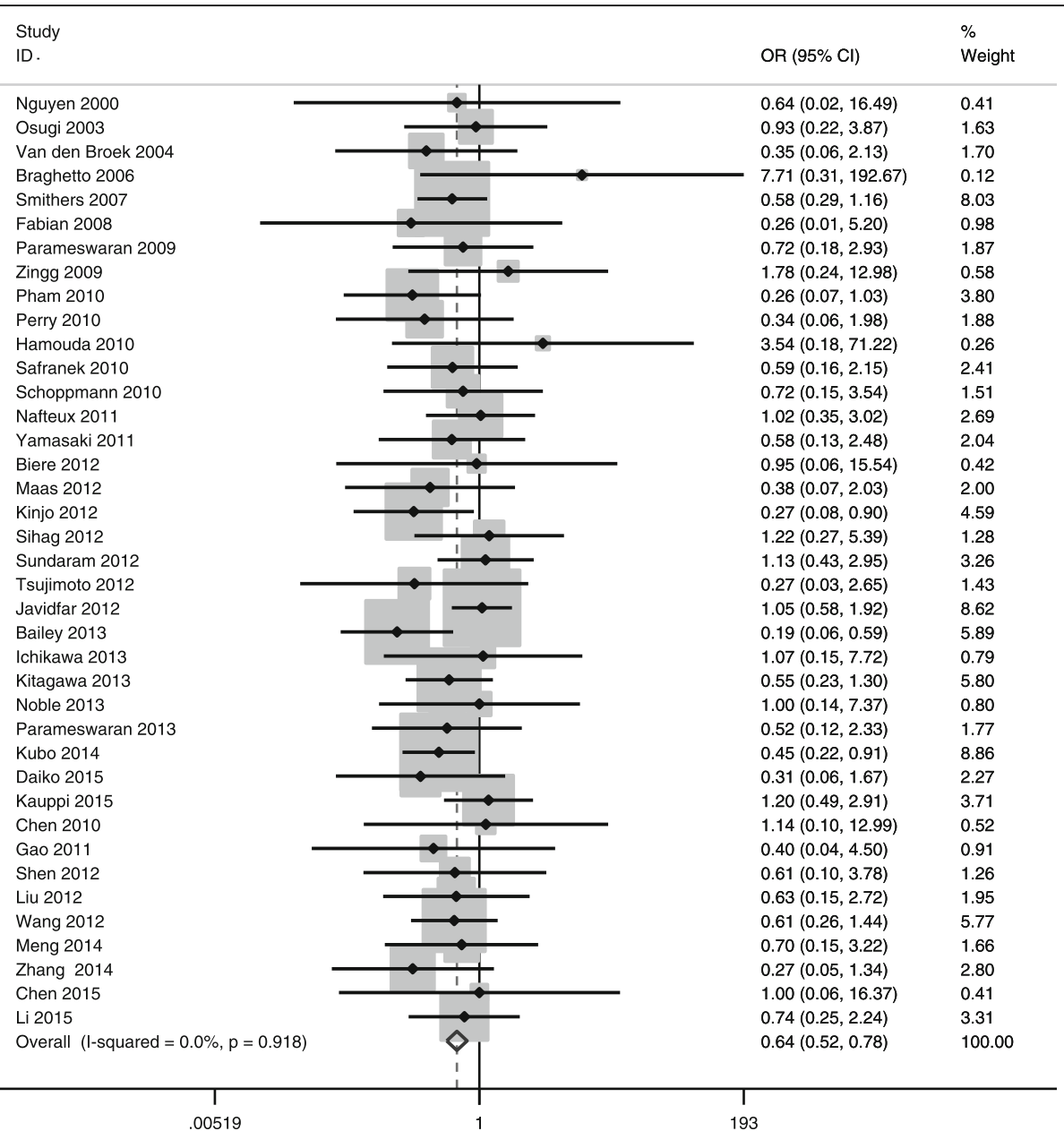

Fig. 8 Meta-analysis of MIE and STR complications

and randomized controlled trials [30] reported, perhaps due to surgeons' familiarization with a new and complex techniques. Blood loss in the MIO group was found to be lower compared with $\mathrm{OE}$, in accordance with the results of several case reported and recently published meta-analyses $[14,20]$.

A shorter hospital stay in the MIO group indicated a faster postoperative recovery than $\mathrm{OE}$ group, consistent with other published meta-analyses [14, 20, 21, 30].

We did not find a significant number of harvested lymph nodes in the MIO group [23]. However, significant heterogeneity was seen among all indices of postoperative data, explained by the fact that postoperative data are dependent on operator and tumor characteristics.

Total complication rates varied between 20.5 and 63.5\% (Table 2). The MIO group showed lower total complication rates, pulmonary complications occupying the major part. However, a number of studies have reported significantly lower pulmonary complications for those who underwent MIO 17.1\% (813/4761) versus OE
$22.6 \%(2264 / 10,020)$, with overall morbidity of $20.8 \%$ $(3077 / 14,781)$, consistent with the result of $3.1-37.0 \%$ from other studies [15-20, 45, 58-76, 95].

Kinugasa et al. and Ferguson et al. [95, 96] noted that development of pneumonia post procedure was associated with worse prognosis for overall survival $(P<0.01)$. In addition, Dumont et al. [97] also showed that two thirds of all fatal complications were respiratory in nature. Sauvanet et al. [98] reported that pulmonary morbidity was associated with age $>60$, with no significant differences in two groups.

The pooled OR of 0.527 showed MIO to be more advantageous than $\mathrm{OE}$ in reducing pulmonary morbidity. Although statistical heterogeneity and publication bias were found, we demonstrated the superiority of MIO through statistical methods. However, several factors have been associated with pulmonary complications post procedure, including preoperative status, intraoperative details, and postoperative details [99].

Gex et al. reported that overall 30-day mortality rate was $4.3 \%$ between 2004 and 2009 , compared with $7.6 \%$ in 


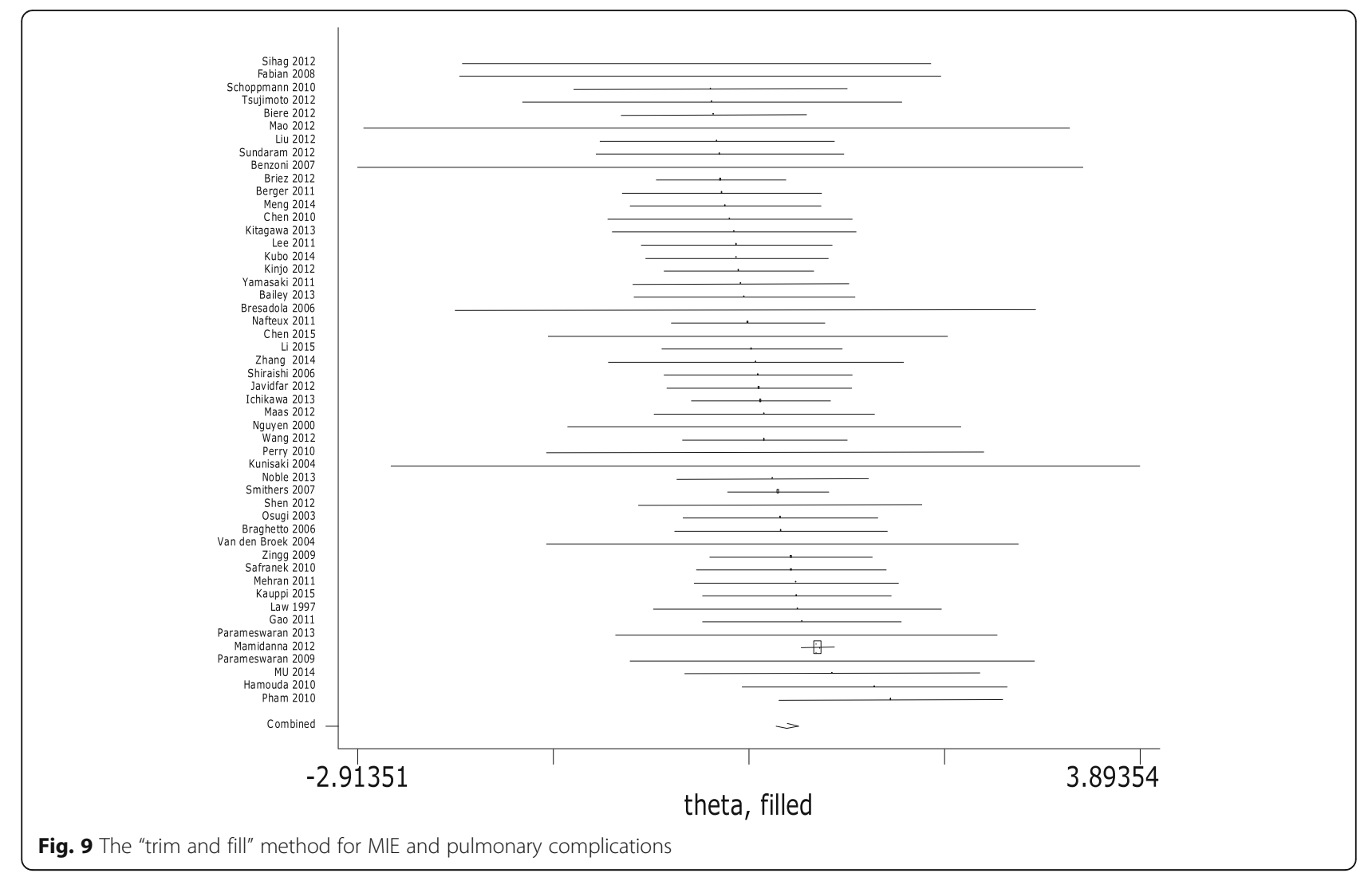

2002 and 2003, and 11.7\% in 1997 and 1999 [100]. Our study found the overall 30 -day mortality rate of $5.8 \%$ and the pooled OR of 0.668 , showing that MIO to be advantageous than $\mathrm{OE}$ in reducing mortality. The main advantages of MIO over conventional OE are minimal trauma, small incision, less blood loss, etc. [6]. Other factors independently associated with 30-day mortality included TNM staging, preoperative neoadjuvant therapy, comorbidity, diabetes, increased age, and intraoperative blood loss. However, there was no difference between two groups in terms of age and comorbidity. We found increased number of patients having neoadjuvant therapy in MIO group and patients selected for MIO were always in the early stages. The bias in the selection of patients may have influenced the accuracy of the conclusion, which should be taken into consideration.

Arrhythmia, heart failure, pulmonary embolism, and other cardiovascular complications are recognized as common problems that caused significant morbidity and mortality. Zhou et al. [24] reported significant decrease in the morbidity of arrhythmia and pulmonary embolism in MIO group. Corresponding to this, (see Table 3), we found MIO to be superior to OE in reducing morbidity of system complications, according to the pooled $\mathrm{OR}=$ 0.777 . Weidenhagent et al. [101] also indicated that the perforation from minimally invasive surgery as such could decrease the risks leading to arrhythmia.
Rizk et al. [102] indicated that "surgical technology related complications," defined as complications caused directly by operative techniques, had no relationship with overall survival post procedure. However, in our meta-analysis, we found strong evidence of reduced risk of STR complications in the MIO group.

Anastomotic leakage (AL) is a serious complication of esophageal resection and is associated with significant morbidity and mortality [4]. In accordance with Zhou et al's conclusion [17], we also did not find the evidence of reduced risk of anastomotic leak in the MIO group. Similarly, we also did not find any significant differences in two groups in terms of RLNP and gastrointestinal complications.

Although we conducted comprehensive meta-analysis, our study still has its limitations. (1) Out of 57 studies, only one study is randomized controlled trial (RCT), while others were case-control or cross-sectional designs. Seven studies were of small sample size, which might have influenced the final results of our study. (2) Patients selected for MIO are unlikely to have been representative of the general population of esophageal cancer. We found more patients having neoadjuvant therapy in MIO group, and the patients selected for MIO were always in the early stages, creating selection bias. (3) In order to highlight the advantages of MIO, surgeons would prefer to publish positive results, and 
Meta-analysis estimates, given named study is omitted

| Lower Cl Limit OEstimate

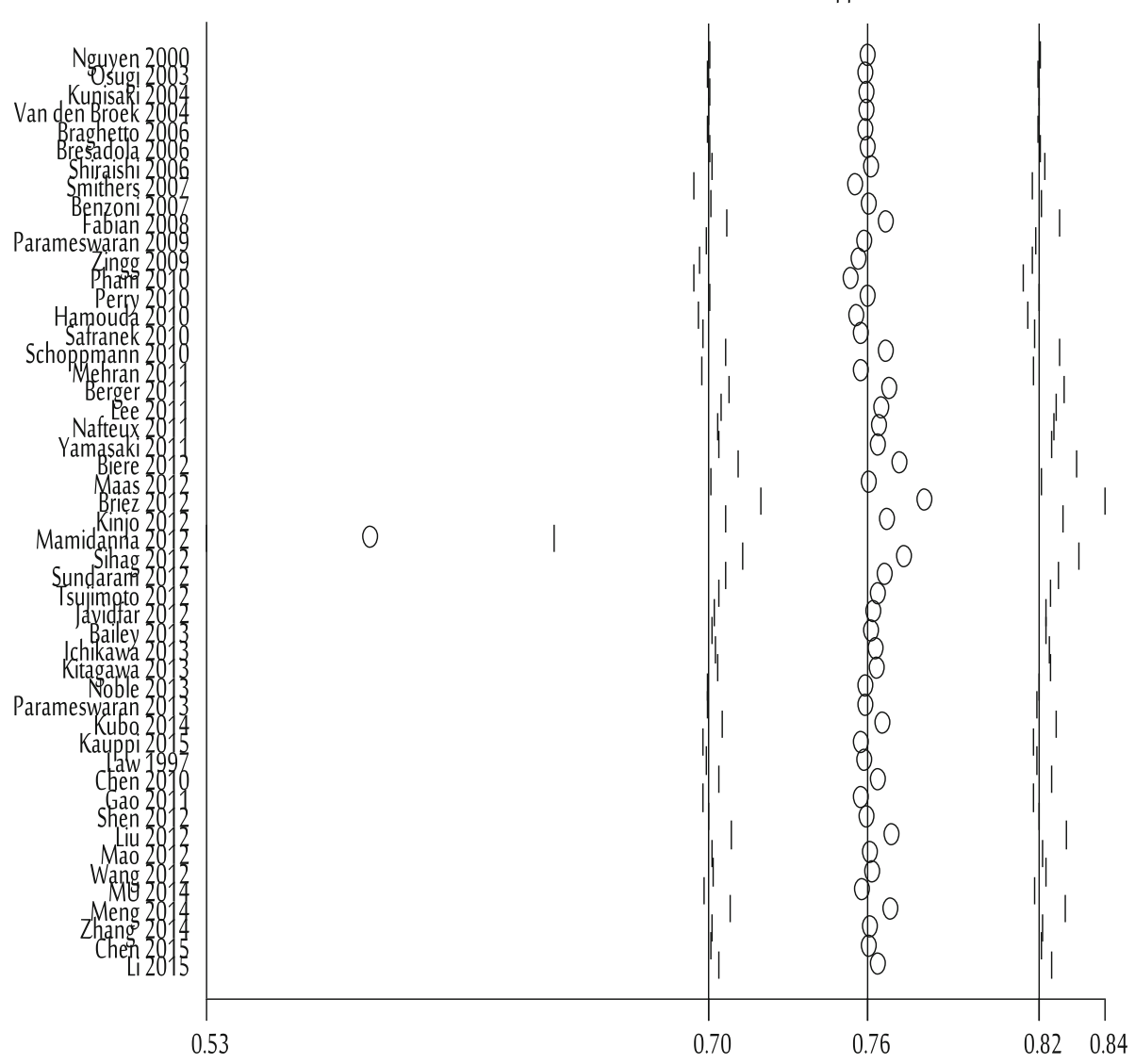

Fig. 10 The sensitivity analysis of MIE and pulmonary complications

unsatisfactory results may have been less inclined in their papers; all these can lead to publication bias. (4) In our study, we compared MIO with OE. MIO consists of different procedures. Although we performed a subgroup analysis according to different procedures, the results were also not qualitatively altered. However, lots of differences exist among these procedures, which will affect the quality of this meta-analysis, and the learning curve of $\mathrm{MIO}$ is quite steep, which may influence the outcome of MIE. These limitations may result in an overestimation or underestimation of the effect of MIO.

In addition, 19 studies did the follow-up visit, and all those studies indicated that the 3-year survival, 5-year survival, and overall recurrence rate did not differ between the two groups. Due to the difficulty in data extraction, no pooled analysis was performed, which may have influential role in this study.

\section{Conclusions}

In summary, this meta-analysis indicates that $\mathrm{MIO}$ is a feasible and a reliable surgical procedure and is superior to $\mathrm{OE}$, with less perioperative complications and in- hospital mortality. However, due to certain limitations of this study, as aforementioned above, further large sample and RCT studies are needed to estimate the effect of $\mathrm{MIO}$ and establish the guidelines for future.

\section{Abbreviations}

MIE: Minimally invasive esophagectomy; MIO: Minimally invasive oesophagectomy; OE: Open esophagectomy; RLNP: Recurrent laryngeal nerve palsy; STR: Surgical technology related; TA: Thoracoscopic assisted

\section{Acknowledgements \\ None.}

\section{Funding}

The authors declare no funding disclosures or sponsors to this study.

\section{Availability of data and materials}

The database supporting the conclusion of this article is included within the article and its additional files (fig file and table file).

\section{Authors' contributions}

YW collected and analyzed the data and drafted the manuscript. WS contributed to the designing, writing, and editing of the manuscript, searching for and adding references, and correspondence with the coauthors. AS and HL offered the technical or material support. All authors read and approved the final manuscript. 


\section{Competing interests}

The authors declare that they have no competing interests.

\section{Consent for publication}

Not applicable.

\section{Ethics approval and consent to participate}

Not applicable.

Received: 10 August 2016 Accepted: 23 November 2016

Published online: 08 December 2016

\section{References}

1. Jemal A, Bray F, Center MM, Ferlay J, Ward E, Forman D. Global cancer statistics. CA Cancer J Clin. 2011;61:69-90.

2. Parkin DM, Pisani P, Ferlay J. Global cancer statistics. CA Cancer J Clin. 1999; 49:33-64. 1.

3. Schweigert M, Dubecz A, Stadlhuber RJ, Muschweck H, Stein HJ. Treatment of intrathoracic esophageal anastomotic leaks by means of endoscopic stent implantation. Interact Cardiovasc Thorac Surg. 2011;12:147-51.

4. Morita M, Nakanoko T, Fujinaka Y, Kubo N, Yamashita N, Yoshinaga K, Saeki H, Emi Y, Kakeji Y, Shirabe K, Maehara Y. In-hospital mortality after a surgical resection for esophageal cancer: analyses of the associated factors and historical changes. Ann Surg Oncol. 2011;18:1757-65.

5. Hulscher JB, van Sandick JW, de Boer AG, Wijnhoven BP, Tijssen JG, Fockens P, Stalmeier PF, Ten KF, van Dekken H, Obertop H, et al. Extended transthoracic resection compared with limited transhiatal resection for adenocarcinoma of the esophagus. N Engl J Med. 2002;347:1662-9.

6. Luketich JD, Alvelo-Rivera M, Buenaventura PO, Christie NA, McCaughan JS, Litle VR, Schauer PR, Close JM, Fernando HC. Minimally invasive esophagectomy: outcomes in 222 patients. Ann Surg. 2003;238:486-94. 494-495.

7. Dimick JB, Staiger DO, Birkmeyer JD. Are mortality rates for different operations related?: implications for measuring the quality of noncardiac surgery. Med Care. 2006;44:774-8.

8. Earlam R, Cunha-Melo JR. Oesophageal squamous cell carcinoma: I. A critical review of surgery. Br J Surg. 1980;67:381-90.

9. Hoppo T, Jobe BA, Hunter JG. Minimally invasive esophagectomy: The evolution and technique of minimally invasive surgery for esophageal cancer. World J Surg. 2011;35:1454-63.

10. Yamamoto M, Weber JM, Karl RC, Meredith KL. Minimally invasive surgery for esophageal cancer: review of the literature and institutional experience Cancer Control. 2013;20:130-7.

11. Sarkaria IS, Rizk NP. Robotic-assisted minimally invasive esophagectomy: the Ivor Lewis approach. Thorac Surg Clin. 2014;24:211-22.

12. D'Journo XB, Thomas PA. Current management of esophageal cancer. J Thorac Dis. 2014;6 Suppl 2:S253-64.

13. Dhamija A, Dhamija A, Hancock J, McCloskey B, Kim AW, Detterbeck FC, Boffa DJ. Minimally invasive oesophagectomy more expensive than open despite shorter length of stay. Eur J Cardiothorac Surg. 2014;45:904-9.

14. Verhage RJ, Hazebroek EJ, Boone J, Van Hillegersberg R. Minimally invasive surgery compared to open procedures in esophagectomy for cancer: a systematic review of the literature. Minerva Chir. 2009:64:135-46.

15. Guo W, Ma X, Yang S, Zhu X, Qin W, Xiang J, Lerut T, Li H. Combined thoracoscopic-laparoscopic esophagectomy versus open esophagectomy: a meta-analysis of outcomes. Surg Endosc. 2016;18(9):5-9.

16. Markar SR, Arya S, Karthikesalingam A, Hanna GB. Technical factors that affect anastomotic integrity following esophagectomy: systematic review and meta-analysis. Ann Surg Oncol. 2013;20:4274-81.

17. Zhou C, Ma G, Li X, Li J, Yan Y, Liu P, He J, Ren Y. Is minimally invasive esophagectomy effective for preventing anastomotic leakages after esophagectomy for cancer?A systematic review and meta-analysis. World J Surg Oncol. 2015;13:269.

18. Gemmill EH, McCulloch P. Systematic review of minimally invasive resection for gastro-oesophageal cancer. Br J Surg. 2007;94:1461-7.

19. Biere SS, Cuesta MA, van der Peet DL. Minimally invasive versus open esophagectomy for cancer: a systematic review and meta-analysis. Minerva Chir. 2009;64:121-33.

20. Nagpal K, Ahmed K, Vats A, Yakoub D, James D, Ashrafian H, Darzi A, Moorthy $K$, Athanasiou T. Is minimally invasive surgery beneficial in the management of esophageal cancer? A meta-analysis. Surg Endosc. 2010;24:1621-9.
21. Sgourakis G, Gockel I, Radtke A, Musholt TJ, Timm S, Rink A, Tsiamis A, Karaliotas C, Lang H. Minimally invasive versus open esophagectomy: metaanalysis of outcomes. Dig Dis Sci. 2010;55:3031-40.

22. Butler N, Collins S, Memon B, Memon MA. Minimally invasive oesophagectomy: current status and future direction. Surg Endosc. 2011;25:2071-83.

23. Dantoc MM, Cox MR, Eslick GD. Does minimally invasive esophagectomy (MIE) provide for comparable oncologic outcomes to open techniques? A systematic review. J Gastrointest Surg. 2012;16:486-94.

24. Zhou C, Zhang L, Wang H, Ma X, Shi B, Chen W, He J, Wang K, Liu P, Ren Y. Superiority of minimally invasive oesophagectomy in reducing in-hospital mortality of patients with resectable oesophageal cancer: a meta-analysis. PLoS One. 2015;10:e132889.

25. Dantoc M, Cox MR, Eslick GD. Evidence to support the use of minimally invasive esophagectomy for esophageal cancer: a meta-analysis. Arch Surg. 2012;147:768-76.

26. Schumer E, Perry K, Melvin WS. Minimally invasive esophagectomy for esophageal cancer: evolution and review. Surg Laparosc Endosc Percutan Tech. 2012;22:383-6.

27. Watanabe M, Baba Y, Nagai Y, Baba H. Minimally invasive esophagectomy for esophageal cancer: an updated review. Surg Today. 2013:43:237-44.

28. Uttley L, Campbell F, Rhodes M, Cantrell A, Stegenga H, Lloyd-Jones M. Minimally invasive oesophagectomy versus open surgery: is there an advantage? Surg Endosc. 2013;27:724-31.

29. Jacobs M, Macefield RC, Elbers RG, Sitnikova K, Korfage IJ, Smets EM, Henselmans I, van Berge HM, de Haes JC, Blazeby JM, Sprangers MA. Metaanalysis shows clinically relevant and long-lasting deterioration in healthrelated quality of life after esophageal cancer surgery. Qual Life Res. 2014;23:1097-115.

30. Biere SS, van Berge HM, Maas KW, Bonavina L, Rosman C, Garcia JR, Gisbertz SS, Klinkenbijl JH, Hollmann MW, de Lange ES, et al. Minimally invasive versus open oesophagectomy for patients with oesophageal cancer: a multicentre, open-label, randomised controlled trial. Lancet. 2012;379:1887-92.

31. Mantel N, Haenszel W. Statistical aspects of the analysis of data from retrospective studies of disease. J Natl Cancer Inst. 1959;22:719-48.

32. DerSimonian R, Laird N. Meta-analysis in clinical trials. Control Clin Trials. 1986;7:177-88.

33. Higgins JP, Thompson SG. Quantifying heterogeneity in a meta-analysis. Stat Med. 2002;21:1539-58

34. Egger M, Davey SG, Schneider M, Minder C. Bias in meta-analysis detected by a simple, graphical test. BMJ. 1997;315:629-34.

35. Willi C, Bodenmann P, Ghali WA, Faris PD, Cornuz J. Active smoking and the risk of type 2 diabetes: a systematic review and meta-analysis. JAMA. 2007; 298:2654-64.

36. The Newcastle-Ottawa Scale (NOS) for assessing the quality of nonrandomised studiesinmeta-analyses. http://www.ohri.ca/programs/ clinical_epidemiology/oxford.asp. Accessed 2 Dec 2016.

37. Higgins JP, Altman DG, Gotzsche PC, Juni P, Moher D, Oxman AD, Savovic J, Schulz KF, Weeks L, Sterne JA. The Cochrane Collaboration's tool for assessing risk of bias in randomised trials. BMJ. 2011;343:d5928.

38. Nguyen NT, Follette DM, Wolfe BM, Schneider PD, Roberts P, Goodnight JJ. Comparison of minimally invasive esophagectomy with transthoracic and transhiatal esophagectomy. Arch Surg. 2000;135:920-5.

39. Osugi H, Takemura M, Higashino M, Takada N, Lee S, Kinoshita H. A comparison of video-assisted thoracoscopic oesophagectomy and radical lymph node dissection for squamous cell cancer of the oesophagus with open operation. Br J Surg. 2003;90:108-13.

40. Kunisaki C, Hatori S, Imada T, Akiyama H, Ono H, Otsuka Y, Matsuda G, Nomura M, Shimada H. Video-assisted thoracoscopic esophagectomy with a voice-controlled robot: the AESOP system. Surg Laparosc Endosc Percutan Tech. 2004;14:323-7.

41. Bernabe KQ, Bolton JS, Richardson WS. Laparoscopic hand-assisted versus open transhiatal esophagectomy: a case-control study. Surg Endosc. 2005; 19:334-7.

42. Van den Broek WT, Makay O, Berends FJ, Yuan JZ, Houdijk AP, Meijer S, Cuesta MA. Laparoscopically assisted transhiatal resection for malignancies of the distal esophagus. Surg Endosc. 2004;18:812-7.

43. Braghetto I, Csendes A, Cardemil G, Burdiles P, Korn O, Valladares H. Open transthoracic or transhiatal esophagectomy versus minimally invasive esophagectomy in terms of morbidity, mortality and survival. Surg Endosc 2006;20:1681-6. 
44. Bresadola V, Terrosu G, Cojutti A, Benzoni E, Baracchini E, Bresadola F. Laparoscopic versus open gastroplasty in esophagectomy for esophageal cancer: a comparative study. Surg Laparosc Endosc Percutan Tech. 2006;16:63-7.

45. Shiraishi T, Kawahara K, Shirakusa T, Yamamoto S, Maekawa T. Risk analysis in resection of thoracic esophageal cancer in the era of endoscopic surgery. Ann Thorac Surg. 2006;81:1083-9.

46. Smithers BM, Gotley DC, Martin I, Thomas JM. Comparison of the outcomes between open and minimally invasive esophagectomy. Ann Surg. 2007;245: 232-40.

47. Benzoni E, Terrosu G, Bresadola V, Uzzau A, Intini S, Noce L, Cedolini C, Bresadola F, De Anna D. A comparative study of the transhiatal laparoscopic approach versus laparoscopic gastric mobilisation and right open transthoracic esophagectomy for esophageal cancer management. J Gastrointestin Liver Dis. 2007;16:395-401.

48. Fabian T, Martin JT, McKelvey AA, Federico JA. Minimally invasive esophagectomy: a teaching hospital's first year experience. Dis Esophagus. 2008:21:220-5

49. Parameswaran R, Veeramootoo D, Krishnadas R, Cooper M, Berrisford R, Wajed S. Comparative experience of open and minimally invasive esophagogastric resection. World J Surg. 2009;33:1868-75.

50. Saha AK, Sutton CD, Sue-Ling H, Dexter SP, Sarela Al. Comparison of oncological outcomes after laparoscopic transhiatal and open esophagectomy for T1 esophageal adenocarcinoma. Surg Endosc. 2009;23:119-24.

51. Zingg U, McQuinn A, DiValentino D, Esterman AJ, Bessell JR, Thompson SK, Jamieson GG, Watson DI. Minimally invasive versus open esophagectomy for patients with esophageal cancer. Ann Thorac Surg. 2009;87:911-9.

52. Pham TH, Perry KA, Dolan JP, Schipper P, Sukumar M, Sheppard BC, Hunter JG. Comparison of perioperative outcomes after combined thoracoscopiclaparoscopic esophagectomy and open Ivor-Lewis esophagectomy. Am J Surg. 2010;199:594-8.

53. Perry KA, Enestvedt CK, Pham T, Welker M, Jobe BA, Hunter JG, Sheppard BC. Comparison of laparoscopic inversion esophagectomy and open transhiatal esophagectomy for high-grade dysplasia and stage I esophageal adenocarcinoma. Arch Surg. 2009;144:679-84.

54. Hamouda AH, Forshaw MJ, Tsigritis K, Jones GE, Noorani AS, Rohatgi A, Botha AJ. Perioperative outcomes after transition from conventional to minimally invasive Ivor-Lewis esophagectomy in a specialized center. Surg Endosc. 2010;24:865-9.

55. Safranek PM, Cubitt J, Booth MI, Dehn TC. Review of open and minimal access approaches to oesophagectomy for cancer. Br J Surg. 2010;97:1845-53.

56. Schoppmann SF, Prager G, Langer FB, Riegler FM, Kabon B, Fleischmann E, Zacherl J. Open versus minimally invasive esophagectomy: a single-center case controlled study. Surg Endosc. 2010;24:3044-53.

57. Schroder W, Holscher AH, Bludau M, Vallbohmer D, Bollschweiler E, Gutschow C. Ivor-Lewis esophagectomy with and without laparoscopic conditioning of the gastric conduit. World J Surg. 2010;34:738-43.

58. Mehran R, Rice D, El-Zein R, Huang JL, Vaporciyan A, Goodyear A, Mehta A Correa A, Walsh G, Roth J, et al. Minimally invasive esophagectomy versus open esophagectomy, a symptom assessment study. Dis Esophagus. 2011 24:147-52.

59. Berger AC, Bloomenthal A, Weksler B, Evans N, Chojnacki KA, Yeo CJ, Rosato EL. Oncologic efficacy is not compromised, and may be improved with minimally invasive esophagectomy. J Am Coll Surg. 2011;212:560-6. 566-568.

60. Lee JM, Cheng JW, Lin MT, Huang PM, Chen JS, Lee YC. Is there any benefit to incorporating a laparoscopic procedure into minimally invasive esophagectomy? The impact on perioperative results in patients with esophageal cancer. World J Surg. 2011;35:790-7.

61. Nafteux P, Moons J, Coosemans W, Decaluwe H, Decker G, De Leyn P, Van Raemdonck D, Lerut T. Minimally invasive oesophagectomy: a valuable alternative to open oesophagectomy for the treatment of early oesophageal and gastro-oesophageal junction carcinoma. Eur J Cardiothorac Surg. 2011;40:1455-63. 1463-1464.

62. Yamasaki M, Miyata H, Fujiwara Y, Takiguchi S, Nakajima K, Kurokawa Y, Mori $M$, Doki $Y$. Minimally invasive esophagectomy for esophageal cancer: comparative analysis of open and hand-assisted laparoscopic abdominal lymphadenectomy with gastric conduit reconstruction. J Surg Oncol. 2011; 104:623-8.

63. Maas KW, Biere SS, Scheepers JJ, Gisbertz SS, Van-der-Peet DL, Cuesta MA. Laparoscopic versus open transhiatal esophagectomy for distal and junction cancer. Rev Esp Enferm Dig. 2012;104:197-202.
64. Briez N, Piessen G, Torres F, Lebuffe G, Triboulet JP, Mariette C. Effects of hybrid minimally invasive oesophagectomy on major postoperative pulmonary complications. Br J Surg. 2012;99:1547-53.

65. Kinjo Y, Kurita N, Nakamura F, Okabe H, Tanaka E, Kataoka Y, Itami A, Sakai Y, Fukuhara S. Effectiveness of combined thoracoscopic-laparoscopic esophagectomy: comparison of postoperative complications and midterm oncological outcomes in patients with esophageal cancer. Surg Endosc. 2012;26:381-90.

66. Mamidanna R, Bottle A, Aylin P, Faiz O, Hanna GB. Short-term outcomes following open versus minimally invasive esophagectomy for cancer in England: a population-based national study. Ann Surg. 2012;255:197-203.

67. Sihag S, Wright CD, Wain JC, Gaissert HA, Lanuti M, Allan JS, Mathisen DJ, Morse CR. Comparison of perioperative outcomes following open versus minimally invasive Ivor Lewis oesophagectomy at a single, high-volume centre. Eur J Cardiothorac Surg. 2012:42:430-7.

68. Sundaram A, Geronimo JC, Willer BL, Hoshino M, Torgersen Z, Juhasz A, Lee TH, Mittal SK. Survival and quality of life after minimally invasive esophagectomy: a single-surgeon experience. Surg Endosc. 2012;26:168-76.

69. Tsujimoto H, Takahata R, Nomura S, Yaguchi $Y$, Kumano I, Matsumoto $Y$, Yoshida K, Horiguchi H, Hiraki S, Ono S, et al. Video-assisted thoracoscopic surgery for esophageal cancer attenuates postoperative systemic responses and pulmonary complications. Surgery. 2012;151:667-73.

70. Javidfar J, Bacchetta M, Yang JA, Miller J, D'Ovidio F, Ginsburg ME, Gorenstein LA, Bessler M, Sonett JR. The use of a tailored surgical technique for minimally invasive esophagectomy. J Thorac Cardiovasc Surg. 2012;143:1125-9.

71. Bailey L, Khan O, Willows E, Somers S, Mercer S, Toh S. Open and laparoscopically assisted oesophagectomy: a prospective comparative study. Eur J Cardiothorac Surg. 2013:43:268-73.

72. Ichikawa H, Miyata G, Miyazaki S, Onodera K, Kamei T, Hoshida T, Kikuchi H, Kanba R, Nakano T, Akaishi T, Satomi S. Esophagectomy using a thoracoscopic approach with an open laparotomic or hand-assisted laparoscopic abdominal stage for esophageal cancer: analysis of survival and prognostic factors in 315 patients. Ann Surg. 2013;257:873-85.

73. Kitagawa H, Namikawa T, Iwabu J, Akimori T, Okabayashi T, Sugimoto T, Mimura T, Kobayashi M, Hanazaki K. Efficacy of laparoscopic gastric mobilization for esophagectomy: comparison with open thoraco-abdominal approach. J Laparoendosc Adv Surg Tech A. 2013;23:452-5.

74. Noble F, Kelly JJ, Bailey IS, Byrne JP, Underwood TJ. A prospective comparison of totally minimally invasive versus open Ivor Lewis esophagectomy. Dis Esophagus. 2013;26:263-71.

75. Parameswaran R, Titcomb DR, Blencowe NS, Berrisford RG, Wajed SA, Streets CG, Hollowood AD, Krysztopik R, Barham CP, Blazeby JM. Assessment and comparison of recovery after open and minimally invasive esophagectomy for cancer: an exploratory study in two centers. Ann Surg Oncol. 2013;20:1970-7.

76. Takeno S, Takahashi Y, Moroga T, Kawahara K, Yamashita Y, Ohtaki M. Retrospective study using the propensity score to clarify the oncologic feasibility of thoracoscopic esophagectomy in patients with esophageal cancer. World J Surg. 2013;37:1673-80.

77. Kubo N, Ohira M, Yamashita Y, Sakurai K, Toyokawa T, Tanaka H, Muguruma K, Shibutani M, Yamazoe S, Kimura K, et al. The impact of combined thoracoscopic and laparoscopic surgery on pulmonary complications after radical esophagectomy in patients with resectable esophageal cancer. Anticancer Res. 2014;34:2399-404.

78. Schneider C, Boddy AP, Fukuta J, Groom WD, Streets CG. Predicting blood transfusion in patients undergoing minimally invasive oesophagectomy. Int J Surg. 2014;12:1342-7.

79. Daiko H, Fujita T. Laparoscopic assisted versus open gastric pull-up following thoracoscopic esophagectomy: A cohort study. Int J Surg. 2015; 19:61-6.

80. Kauppi J, Rasanen J, Sihvo E, Huuhtanen R, Nelskyla K, Salo J. Open versus minimally invasive esophagectomy: clinical outcomes for locally advanced esophageal adenocarcinoma. Surg Endosc. 2015;29:2614-9.

81. Law S. Minimally invasive techniques for oesophageal cancer surgery. Best Pract Res Clin Gastroenterol. 2006;20:925-40.

82. Chen BF, Zhu CC, Wang CG, Ma DH, Lin J, Zhang B, Kong M. Clinical comparative study of minimally invasive esophagectomy versus open esophagectomy for esophageal carcinoma. Zhonghua Wai Ke Za Zhi. 2010; 48:1206-9.

83. Gao Y, Wang Y, Chen L, Zhao Y. Comparison of open three-field and minimally-invasive esophagectomy for esophageal cancer. Interact Cardiovasc Thorac Surg. 2011;12:366-9. 
84. Shen $Y$, Zhang $Y$, Tan L, Feng $M$, Wang $H$, Khan MA, Liang M, Wang $Q$. Extensive mediastinal lymphadenectomy during minimally invasive esophagectomy: optimal results from a single center. J Gastrointest Surg. 2012;16:715-21.

85. Liu BX, Li Y, Qin JJ, Zhang RX, Liu XB, Sun HB, Liu SL. Comparison of thoraco-laparoscopic and open three-field subtotal esophagectomy for esophageal cancer. Zhonghua Wei Chang Wai Ke Za Zhi. 2012;15:938-42.

86. Mao T, Fang WT, Gu ZT, Yao F, Guo XF, Chen WH. Comparative study of perioperative complications and lymphadenectomy between minimally invasive esophagectomy and open procedure. Zhonghua Wei Chang Wai Ke Za Zhi. 2012;15:922-5.

87. Wang H, Tan LJ, Li JP, Shen YX, Zhang Y, Feng MX, Wang Q. Evaluation of safety of video-assisted thoracoscopic esophagectomy for esophageal carcinoma. Zhonghua Wei Chang Wai Ke Za Zhi. 2012;15:926-9.

88. Mu J, Yuan Z, Zhang B, Li N, Lyu F, Mao Y, Xue Q, Gao S, Zhao J, Wang D, et al. Comparative study of minimally invasive versus open esophagectomy for esophageal cancer in a single cancer center. Chin Med J (Engl). 2014; 127:747-52.

89. Meng F, Li Y, Ma H, Yan M, Zhang R. Comparison of outcomes of open and minimally invasive esophagectomy in 183 patients with cancer. J Thorac Dis. 2014;6:1218-24.

90. Zhang J, Xu M, Guo M, Mei X, Liu C. Analysis of postoperative quality of life in patients with middle thoracic esophageal carcinoma undergoing minimally invasive Ivor-Lewis esophagectomy. Zhonghua Wei Chang Wai Ke Za Zhi. 2014;17:915-9.

91. Chen $X$, Yang J, Peng J, Jiang H. Case-matched analysis of combined thoracoscopic-laparoscopic versus open esophagectomy for esophageal squamous cell carcinoma. Int J Clin Exp Med. 2015;8:13516-23.

92. Yang J, Lyu B, Zhu W, Chen J, He J, Tang S. A retrospective cohort comparison of esophageal carcinoma between thoracoscopic and laparoscopic esophagectomy and open esophagectomy. Zhonghua Wai Ke Za Zhi. 2015;53:378-81.

93. Li J, Shen Y, Tan L, Feng M, Wang H, Xi Y, Wang Q. Is minimally invasive esophagectomy beneficial to elderly patients with esophageal cancer? Surg Endosc. 2015;29:925-30.

94. Wallner G, Zgodzinski W, Masiak-Segit W, Skoczylas T, Dabrowski A. Minimally invasive surgery for esophageal cancer - benefits and controversies. Kardiochir Torakochirurgia Pol. 2014;11:151-5.

95. Ferguson MK, Durkin AE. Preoperative prediction of the risk of pulmonary complications after esophagectomy for cancer. J Thorac Cardiovasc Surg. 2002;123:661-9.

96. Kinugasa S, Tachibana M, Yoshimura H, Ueda S, Fujii T, Dhar DK, Nakamoto T, Nagasue N. Postoperative pulmonary complications are associated with worse short- and long-term outcomes after extended esophagectomy. J Surg Oncol. 2004;88:71-7.

97. Dumont P, Wihlm JM, Hentz JG, Roeslin N, Lion R, Morand G. Respiratory complications after surgical treatment of esophageal cancer. A study of 309 patients according to the type of resection. Eur J Cardiothorac Surg. 1995;9:539-43.

98. Sauvanet A, Mariette C, Thomas P, Lozac'H P, Segol P, Tiret E, Delpero JR, Collet $\mathrm{D}$, Leborgne J, Pradere $\mathrm{B}$, et al. Mortality and morbidity after resection for adenocarcinoma of the gastroesophageal junction: predictive factors. J Am Coll Surg. 2005;201:253-62.

99. D'Amico TA. Outcomes after surgery for esophageal cancer. Gastrointest Cancer Res. 2007;1:188-96.

100. Gex G, Gerstel E, Righini M, LE Gal G, Aujesky D, Roy PM, Sanchez O, Verschuren F, Rutschmann OT, Perneger T, Perrier A. Is atrial fibrillation associated with pulmonary embolism? J Thromb Haemost. 2012;10:347-51.

101. Weidenhagen R, Hartl WH, Gruetzner KU, Eichhorn ME, Spelsberg F, Jauch KW. Anastomotic leakage after esophageal resection: new treatment options by endoluminal vacuum therapy. Ann Thorac Surg. 2010;90:1674-81.

102. Rizk NP, Bach PB, Schrag D, Bains MS, Turnbull AD, Karpeh M, Brennan MF, Rusch WW. The impact of complications on outcomes after resection for esophageal and gastroesophageal junction carcinoma. J Am Coll Surg. 2004:198:42-50.

\section{Submit your next manuscript to BioMed Central and we will help you at every step:}

- We accept pre-submission inquiries

- Our selector tool helps you to find the most relevant journal

- We provide round the clock customer support

- Convenient online submission

- Thorough peer review

- Inclusion in PubMed and all major indexing services

- Maximum visibility for your research

Submit your manuscript at www.biomedcentral.com/submit 